DOE/ID-22210

Prepared in cooperation with the U.S. Department of Energy

\title{
Completion Summary for Well NRF-16 near the Naval Reactors Facility, Idaho National Laboratory, Idaho
}

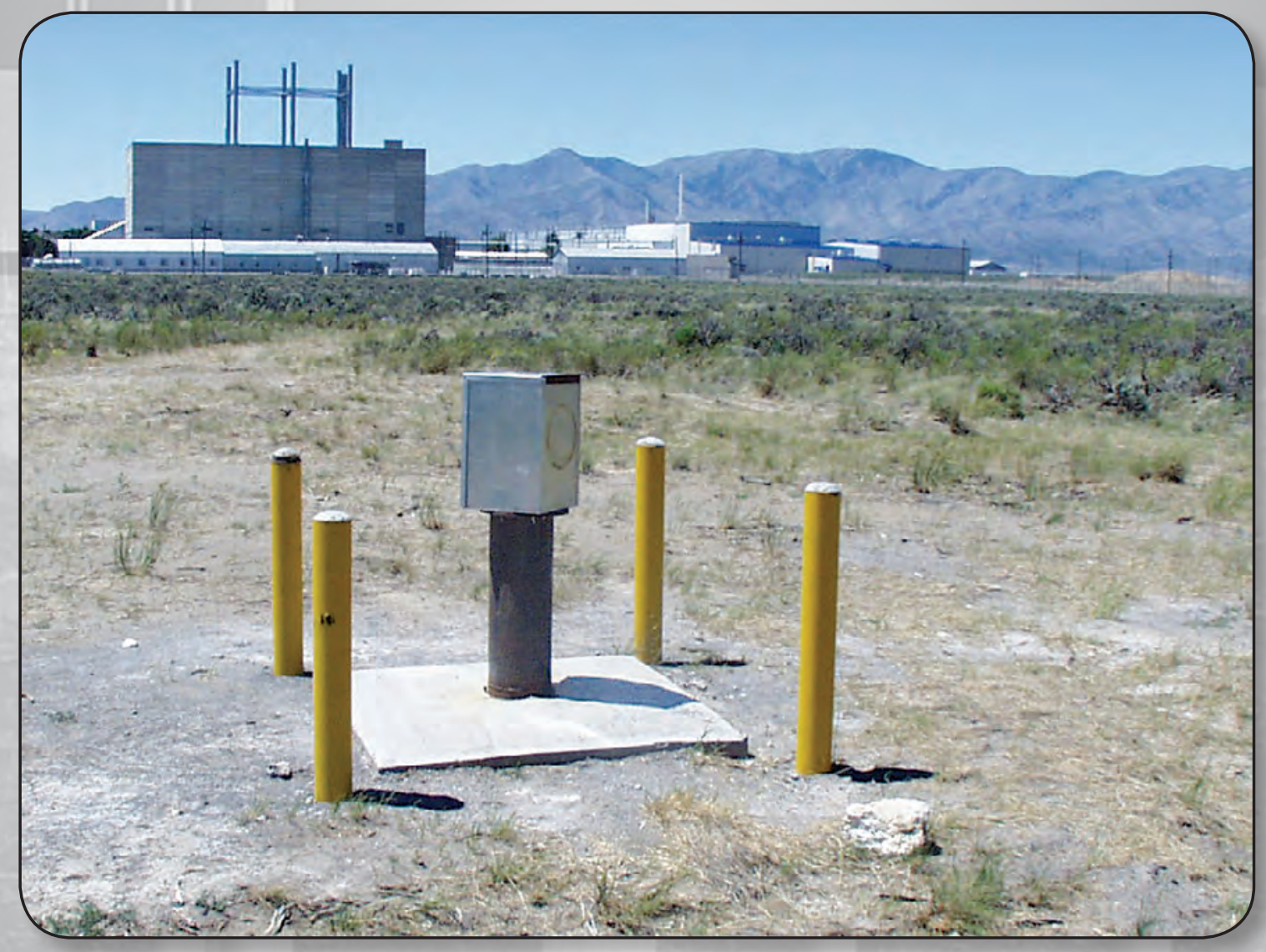

Scientific Investigations Report 2010-5101 
Cover: Photograph courtesy of USGS INL Project Office. 


\section{Completion Summary for Well NRF-16 near the Naval Reactors Facility, Idaho National Laboratory, Idaho}

By Brian V. Twining, Jason C. Fisher, and Roy C. Bartholomay

DOE/ID-22210

Prepared in cooperation with the U.S. Department of Energy

Scientific Investigations Report 2010-5101 


\title{
U.S. Department of the Interior \\ KEN SALAZAR, Secretary
}

\section{U.S. Geological Survey \\ Marcia K. McNutt, Director}

\section{U.S. Geological Survey, Reston, Virginia: 2010}

\begin{abstract}
For more information on the USGS - the Federal source for science about the Earth, its natural and living resources, natural hazards, and the environment, visit http://www.usgs.gov or call 1-888-ASK-USGS

For an overview of USGS information products, including maps, imagery, and publications, visit http://www.usgs.gov/pubprod

To order this and other USGS information products, visit http://store.usgs.gov
\end{abstract}

Any use of trade, product, or firm names is for descriptive purposes only and does not imply endorsement by the U.S. Government.

Although this report is in the public domain, permission must be secured from the individual copyright owners to reproduce any copyrighted materials contained within this report.

Suggested citation:

Twining, B.V., Fisher, J.C., and Bartholomay, R.C., 2010, Completion summary for well NRF-16 near the Naval Reactors Facility, Idaho National Laboratory, Idaho: U.S. Geological Survey Scientific Investigations Report 2010-5101, 36 p. 


\section{Contents}

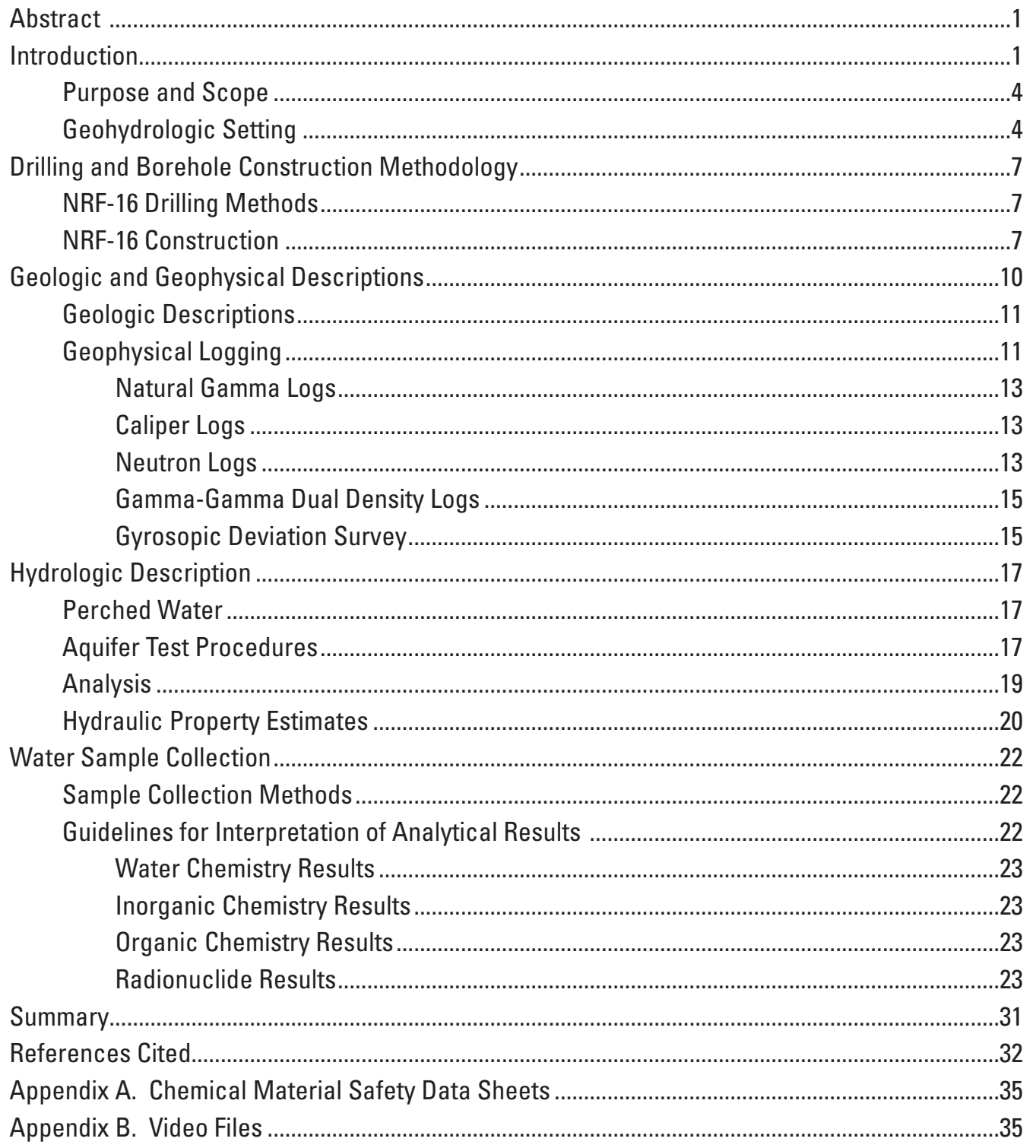




\section{Figures}

Figure 1. Map showing location of selected facilities and monitoring well NRF-16, Naval Reactors Facility, Idaho National Laboratory, Idaho

Figure 2. Map showing location of monitoring wells, Naval Reactors Facility and vicinity, Idaho National Laboratory, Idaho

Figure 3. Diagram and graphs showing idealized typical olivine tholeiitic pahoehoe basalt flow.

Figure 4. Map showing water-table contours, measured during March-May 2008, and monitoring wells at and near the Idaho National Laboratory, Idaho

Figure 5. Diagram and photographs showing PQ-size coring system, similar to one used for coring well NRF-16, Naval Reactors Facility, Idaho National Laboratory, Idaho

Figure 6. Diagram showing final design of monitoring well NRF-16, Naval Reactors Facility, Idaho National Laboratory, Idaho...

Figure 7. Diagram of geophysical and lithologic logs run from total depth to land surface for borehole NRF-16, Naval Reactors Facility, Idaho National Laboratory, Idaho

Figure 8. Diagram of geophysical and lithologic logs with focus on depths 360-424 feet below land surface for NRF-16, Naval Reactors Facility, Idaho National Laboratory, Idaho

Figure 9. Diagram of geophysical log traces run before and after placing cement grout in borehole NRF-16, Naval Reactors Facility, Idaho National Laboratory, Idaho

Figure 10. Diagram showing idealized placement of sensor during the aquifer tests, Naval Reactors Facility, Idaho National Laboratory, Idaho

Figure 11. Graphs showing changes in compensated pressure head, barometric head, fluid temperature, and air temperature through time during aquifer tests, Naval Reactors Facility, Idaho National Laboratory, Idaho, November 16-17, 2009

Figure 12. Graph showing pumping rates during the aquifer tests, Naval Reactors Facility, Idaho National Laboratory, Idaho, November 16-17, 2009

Figure 13. Graph showing analysis of drawdown time series for aquifer test 1 at well NRF-16, Naval Reactors Facility, Idaho National Laboratory, Idaho, November 16, 2009

Figure 14. Graph showing analysis of drawdown time series for aquifer test 2 at well NRF-16, Naval Reactors Facility, Idaho National Laboratory, Idaho, November 16, 2009 ...... 


\section{Tables}

Table 1. Location and completion information for monitoring well NRF-16, Naval Reactors Facility, Idaho National Laboratory, Idaho

Table 2. Summary of geophysical and video logs collected at well NRF-16, Naval Reactors Facility, Idaho National Laboratory, Idaho .......................... 11

Table 3. Gyroscopic deviation survey summary from well NRF-16, Naval Reactors Facility, Idaho National Laboratory, Idaho

Table 4. Comparison of transmissivity values estimated from aquifer tests conducted at wells near well NRF-16, near the Naval Reactors Facility, Idaho National Laboratory, Idaho

Table 5. Concentrations of selected radiochemical and chemical constituents in water from wells USGS 17, NRF-15, and NRF-16, near the Naval Reactors Facility, Idaho National Laboratory, Idaho

\section{Conversion Factors, Datums, Abbreviations and Acronyms}

Conversion Factors

\begin{tabular}{|c|c|c|}
\hline Multiply & By & To obtain \\
\hline \multicolumn{3}{|c|}{ Length } \\
\hline inch (in.) & 2.54 & centimeter $(\mathrm{cm})$ \\
\hline foot $(\mathrm{ft})$ & 0.3048 & $\operatorname{meter}(\mathrm{m})$ \\
\hline mile (mi) & 1.609 & kilometer (km) \\
\hline yard (yd) & 0.9144 & meter $(\mathrm{m})$ \\
\hline \multicolumn{3}{|c|}{ Area } \\
\hline square foot $\left(\mathrm{ft}^{2}\right)$ & 0.09290 & square meter $\left(\mathrm{m}^{2}\right)$ \\
\hline \multicolumn{3}{|c|}{ Volume } \\
\hline ounce, fluid (fl. oz) & 0.02957 & liter (L) \\
\hline gallon (gal) & 3.785 & liter (L) \\
\hline cubic foot $\left(\mathrm{ft}^{3}\right)$ & 28.32 & cubic decimeter $\left(\mathrm{dm}^{3}\right)$ \\
\hline cubic foot $\left(\mathrm{ft}^{3}\right)$ & 0.02832 & cubic meter $\left(\mathrm{m}^{3}\right)$ \\
\hline cubic yard $\left(\mathrm{yd}^{3}\right)$ & 0.7646 & cubic meter $\left(\mathrm{m}^{3}\right)$ \\
\hline liter $(\mathrm{L})$ & 33.82 & ounce, fluid (fl. oz) \\
\hline \multicolumn{3}{|c|}{ Flow rate } \\
\hline foot per second (ft/s) & 0.3048 & meter per second $(\mathrm{m} / \mathrm{s})$ \\
\hline foot per minute ( $\mathrm{ft} / \mathrm{min})$ & 0.3048 & meter per minute $(\mathrm{m} / \mathrm{min})$ \\
\hline foot per hour $(\mathrm{ft} / \mathrm{hr})$ & 0.3048 & meter per hour $(\mathrm{m} / \mathrm{hr})$ \\
\hline foot per day $(\mathrm{ft} / \mathrm{d})$ & 0.3048 & meter per day $(\mathrm{m} / \mathrm{d})$ \\
\hline foot per year $(\mathrm{ft} / \mathrm{yr})$ & 0.3048 & meter per year $(\mathrm{m} / \mathrm{yr})$ \\
\hline gallon per minute (gal/min) & 0.06309 & liter per second $(\mathrm{L} / \mathrm{s})$ \\
\hline \multicolumn{3}{|c|}{ Pressure } \\
\hline atmosphere, standard (atm) & 101.3 & kilopascal $(\mathrm{kPa})$ \\
\hline pound per square inch $\left(\mathrm{lb} / \mathrm{in}^{2}\right)$ & 6.895 & kilopascal $(\mathrm{kPa})$ \\
\hline \multicolumn{3}{|c|}{ Radioactivity } \\
\hline picocurie per liter $(\mathrm{pCi} / \mathrm{L})$ & 0.037 & becquerel per liter $(\mathrm{Bq} / \mathrm{L})$ \\
\hline
\end{tabular}




\section{Conversion Factors, Datums, Abbreviations and Acronyms}

Conversion Factors-Continued

\begin{tabular}{lcc}
\hline \multicolumn{1}{c}{ Multiply } & By & To obtain \\
\hline foot per day $(\mathrm{ft} / \mathrm{d})$ & Hydraulic conductivity & \\
\hline & 0.3048 & meter per day $(\mathrm{m} / \mathrm{d})$ \\
\hline foot per mile $(\mathrm{ft} / \mathrm{mi})$ & Hydraulic gradient & \\
\hline & 0.1894 & meter per kilometer $(\mathrm{m} / \mathrm{km})$ \\
\hline foot squared per day $\left(\mathrm{ft}^{2} / \mathrm{d}\right)$ & Transmissivity* & \\
\hline
\end{tabular}

Temperature in degrees Celsius $\left({ }^{\circ} \mathrm{C}\right)$ may be converted to degrees Fahrenheit $\left({ }^{\circ} \mathrm{F}\right)$ as follows:

$$
{ }^{\circ} \mathrm{F}=\left(1.8 \times^{\circ} \mathrm{C}\right)+32 \text {. }
$$

Specific conductance is given in microsiemens per centimeter at 25 degrees Celsius $(\mu \mathrm{S} / \mathrm{cm}$ at $\left.25^{\circ} \mathrm{C}\right)$.

Concentrations of chemical constituents in water are given either in milligrams per liter (mg/L) or micrograms per liter $(\mu \mathrm{g} / \mathrm{L})$.

*Transmissivity: The standard unit for transmissivity is cubic foot per day per square foot times foot of aquifer thickness [(ft $\left.\left.\mathrm{ft}^{3} / \mathrm{d}\right) / \mathrm{ft}^{2}\right] \mathrm{ft}$. In this report, the mathematically reduced form, foot squared per day $\left(\mathrm{ft}^{2} / \mathrm{d}\right)$, is used for convenience.

Datums

Vertical coordinate information is referenced to National Geodetic Vertical Datum of 1929 (NGVD 29).

Horizontal coordinate information is referenced to North American Datum of 1927 (NAD 27).

Altitude, as used in this report, refers to distance above the vertical datum.

Abbreviations and Acronyms

\begin{tabular}{ll}
\hline BLS & below land surface \\
CERCLA & Comprehensive Environmental Response Compensation and Liability Act \\
CFA & Central Facilities Area \\
SRP & Snake River Plain \\
INL & Idaho National Laboratory \\
LAS & Log ASCII Standard \\
LRL & laboratory reporting level \\
MSDS & Material Safety Data Sheet \\
NRF & Naval Reactors Facility \\
NRLFO/IBO & U.S. Department of Energy's Naval Reactors Laboratory Field Office, Idaho \\
& $\quad$ Branch Office \\
NWOL & USGS National Water Quality Laboratory \\
RL & reporting limits \\
SS & stainless steel \\
SSD & short-spaced density \\
LSD & long-spaced density \\
USGS & U.S. Geological Survey \\
\hline
\end{tabular}




\title{
Completion Summary for Well NRF-16 near the Naval Reactors Facility, Idaho National Laboratory, Idaho
}

\author{
By Brian V. Twining, Jason C. Fisher, and Roy C. Bartholomay
}

\section{Abstract}

In 2009, the U.S. Geological Survey in cooperation with the U.S. Department of Energy's Naval Reactors Laboratory Field Office, Idaho Branch Office cored and completed well NRF-16 for monitoring the eastern Snake River Plain (SRP) aquifer. The borehole was initially cored to a depth of 425 feet below land surface and water samples and geophysical data were collected and analyzed to determine if well NRF-16 would meet criteria requested by Naval Reactors Facility (NRF) for a new upgradient well. Final construction continued after initial water samples and geophysical data indicated that NRF-16 would produce chemical concentrations representative of upgradient aquifer water not influenced by NRF facility disposal, and that the well was capable of producing sustainable discharge for ongoing monitoring. The borehole was reamed and constructed as a Comprehensive Environmental Response Compensation and Liability Act monitoring well complete with screen and dedicated pump.

Geophysical and borehole video logs were collected after coring and final completion of the monitoring well. Geophysical logs were examined in conjunction with the borehole core to identify primary flow paths for groundwater, which are believed to occur in the intervals of fractured and vesicular basalt and to describe borehole lithology in detail. Geophysical data also were examined to look for evidence of perched water and the extent of the annular seal after cement grouting the casing in place. Borehole videos were collected to confirm that no perched water was present and to examine the borehole before and after setting the screen in well NRF-16.

Two consecutive single-well aquifer tests to define hydraulic characteristics for well NRF-16 were conducted in the eastern SRP aquifer. Transmissivity and hydraulic conductivity averaged from the aquifer tests were $4.8 \times 10^{3} \mathrm{ft}^{2} / \mathrm{d}$ and $9.9 \mathrm{ft} / \mathrm{d}$ respectively. The transmissivity for well NRF-16 was within the range of values determined from past aquifer tests in other wells near NRF of $4.4 \times 10^{2}$ to $5.1 \times 10^{5} \mathrm{ft}^{2} / \mathrm{d}$.

Water samples were analyzed for metals, nutrients, total organic carbon, volatile organic compounds, semi-volatile organic compounds, herbicides, pesticides, polychlorinated biphenols, and radionuclides. All chloride, nitrate, and sulfate concentrations were less than background concentrations for the eastern SRP aquifer north of the NRF. Concentrations in water samples for most of the organic compounds and radionuclides were less than the reporting limits and reporting levels.

\section{Introduction}

The U.S. Geological Survey (USGS), in cooperation with the U.S. Department of Energy, has collected drill hole information at the Idaho National Laboratory (INL) since 1949 to provide baseline data concerning the migration and disposition of radioactive and chemical wastes in the eastern Snake River Plain (SRP) aquifer. The USGS is developing models for the movement of water in the eastern SRP aquifer and more geohydrologic and corehole information near the Naval Reactors Facility (NRF) is needed. Geohydrologic information is needed to help understand flow-system response to large recharge events to the north and east of the NRF in the Big Lost River and its playas and sinks (fig. 1) and corehole information will help define the basalt and sediment stratigraphy for that region of the aquifer.

In 2008, in response to a request from the U.S. Department of Energy's Naval Reactors Laboratory Field Office, Idaho Branch Office (NRLFO/IBO) to drill a replacement well for NRF-13, the USGS INL Project Office cored a borehole (NRF-15) about 0.25 mi north of well NRF-13 to a depth of about $425 \mathrm{ft}$. After coring, the water from NRF-15 was sampled to see if aquifer conditions were conducive to installing a replacement monitoring well for the NRF groundwater monitoring program (fig. 2). The NRF criteria for a new replacement monitoring well included: (1) the well is unaffected by NRF facility operations, (2) the well is capable of producing a sustained pumping rate of $15 \mathrm{gal} / \mathrm{min}$ or higher, and (3) sampled water has low turbidity levels (Kelly Willie, Bechtel/Bettis Corporation, written commun., April 6, 2009). Water samples collected from well NRF-15 on November 20, 2008, and December 10, 2008, indicated larger than background concentrations of chloride and sulfate. After reviewing the data, NRF determined that NRF-15 would not meet their needs as an upgradient monitoring well (Kelly Willie, Bechtel/Bettis Corporation, oral commun., August 27, 2009) and it was decided to drill a second monitoring well farther north, NRF-16. 


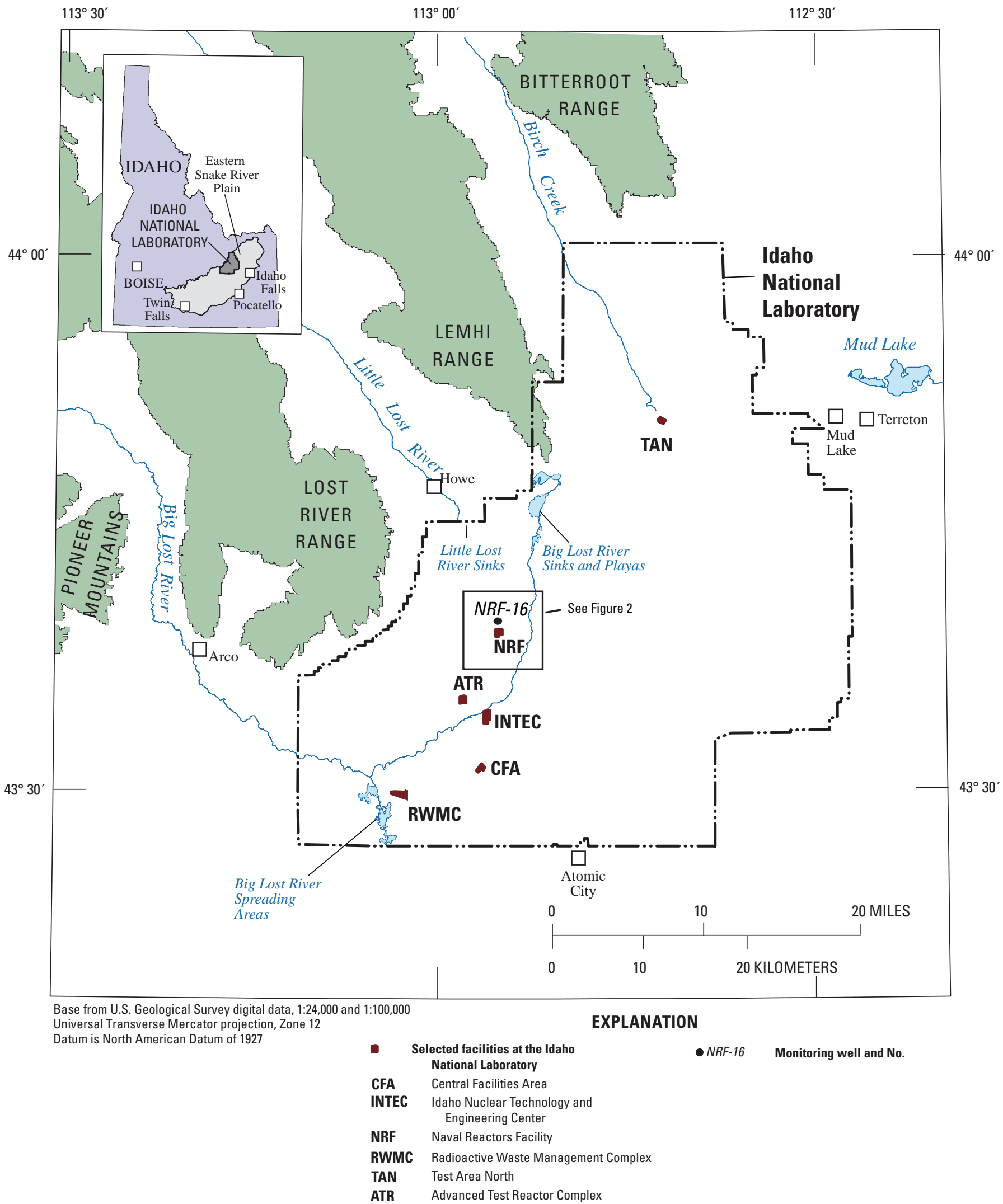

Figure 1. Location of selected facilities and monitoring well NRF-16, Naval Reactors Facility, Idaho National Laboratory, Idaho. 


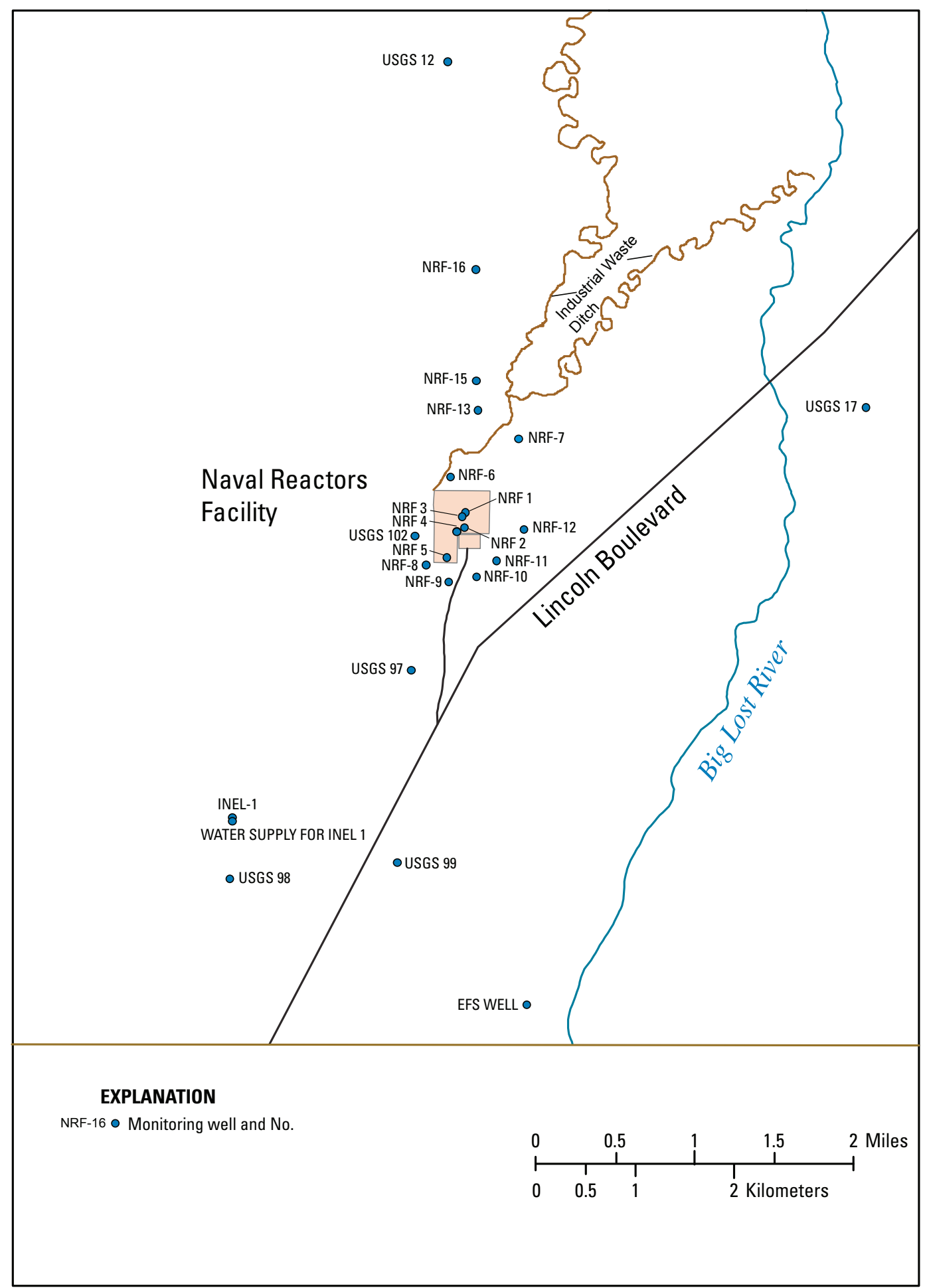

Figure 2. Location of monitoring wells, Naval Reactors Facility and vicinity, Idaho National Laboratory, Idaho. 
During summer 2009, a new well (NRF-16) about $1 \mathrm{mi}$ north of NRF-15 (ig. 2) was continuously cored and water samples collected to determine if this location would meet the needs for the NRF Program. Analysis of water samples collected August 26, 2009, indicated that well NRF-16 would meet NRF criteria for an upgradient monitoring well (Kelly Willie, Bechtel/Bettis Corporation, oral commun., August 27, 2009), and the USGS proceeded to complete the borehole as a Comprehensive Environmental Response Compensation and Liability Act monitoring well.

\section{Purpose and Scope}

The purpose of this report is to present information collected during the drilling, completion, and testing of NRF-16, a new upgradient monitoring well for the NRF groundwater monitoring program. Geophysical data collected during drilling and after final completion of the well are presented and analyzed. The production results of two consecutive hydraulic pumping tests, performed after completion of the monitoring well, are presented. Water samples were collected and analyzed for common ions, selected trace elements, and nutrients prior to well completion to obtain preliminary information on local water chemistry of the eastern SRP aquifer. Samples also were collected and analyzed for a comprehensive suite of chemical constituents selected by the NRF (Kelly Willie, Bechtel/Bettis Corporation, written communication, October 21,2009) after completion of the well.

\section{Geohydrologic Setting}

The INL is in the west-central part of the eastern SRP (fig. 1). The eastern SRP is a northeast-trending structural basin about $200 \mathrm{mi}$ long and 50-70 mi wide. The basin, bounded by faults on the northwest and by downwarping and faulting on southeast, has been filled with basaltic lava flows interbedded with terrestrial sediments. The basaltic rocks and sedimentary deposits combine to form the eastern SRP aquifer, which is the main source of groundwater for the eastern SRP.

The eastern SRP aquifer is one of the most productive aquifers in the United States (U.S. Geological Survey, 1985, p. 193). Movement of water in the aquifer generally is from northeast to southwest, and it eventually discharges to springs along the Snake River downstream from Twin Falls, Idahoabout $100 \mathrm{mi}$ southwest of the INL. Water moves horizontally through basalt interflow zones and vertically through joints and interfingering edges of interflow zones. Infiltration of surface water, heavy pumpage, geologic conditions, and seasonal fluxes of recharge and discharge locally affect the movement of groundwater (Garabedian, 1986). Recharge to the eastern SRP aquifer is primarily from infiltration of applied irrigation water, streamflow, precipitation, and groundwater inflow from adjoining mountain drainage basins (Ackerman and others, 2006).

The eastern SRP aquifer is comprised mostly of olivine tholeiite basalt flows, erupted as tube-fed, inflated pahoehoe flows that comprise more than 85 percent of the subsurface volume of the eastern SRP at the INL (Anderson and Liszewski, 1997). Figure 3 illustrates a typical eastern SRP basalt flow showing vesicular zones and cooling fractures on the top and sides, with vesicle sheets, pipe vesicles, interior mega-vesicles, and a diktytaxitic to massive core. Near-vent flows are thinner than distal flows, and accumulations of thin flows have a larger volume of high conductivity zones than the same volume of thick flows; therefore, spaces occupied by vents tend to have more fractured, high-conductivity volume than spaces distal to vents (Anderson and others, 1999). The distribution of basalt flows is controlled by topography, rate of effusion, and duration of eruption.

Across the INL, the water table altitude in boreholes ranges from about 4,560 to 4,400 ft (fig. 4); near NRF the altitude of the water table is about 4,470 ft. Depth to water ranges from about $200 \mathrm{ft}$ north of the INL to more than $900 \mathrm{ft}$ in the southeastern area; depth to water near the NRF is about $360 \mathrm{ft}$ below land surface (BLS). A significant proportion of the groundwater moves through the upper $200-800 \mathrm{ft}$ of basaltic rocks (Mann, 1986, p. 21). A range of transmissivity of basalt in the upper part of the aquifer of 1.1 to $760,000 \mathrm{ft}^{2} / \mathrm{d}$ was reported by Ackerman (1991, p. 30) and Bartholomay, Tucker, and others (1997b, table 3). The hydraulic gradient at the INL ranges from 2 to $10 \mathrm{ft} / \mathrm{mi}$, with an average of about $4 \mathrm{ft} / \mathrm{mi}$ (Davis, 2008, fig. 11). Horizontal flow velocities of 2 to $20 \mathrm{ft} / \mathrm{d}$ have been calculated based on the movement of various chemical/radiochemical constituents in different areas of the eastern SRP aquifer at the INL (Robertson and others, 1974; Mann and Beasley, 1994; Cecil and others, 2000; Busenberg and others, 2001). These flow rates equate to a travel time of about 70-700 years for water beneath the INL to travel to springs that discharge at the terminus of the eastern SRP aquifer near Twin Falls, Idaho (fig. 1). Localized tracer tests at the INL have shown vertical and horizontal transport rates as high as 60 to $150 \mathrm{ft} / \mathrm{d}$ (Nimmo and others, 2002; Duke and others, 2007). 


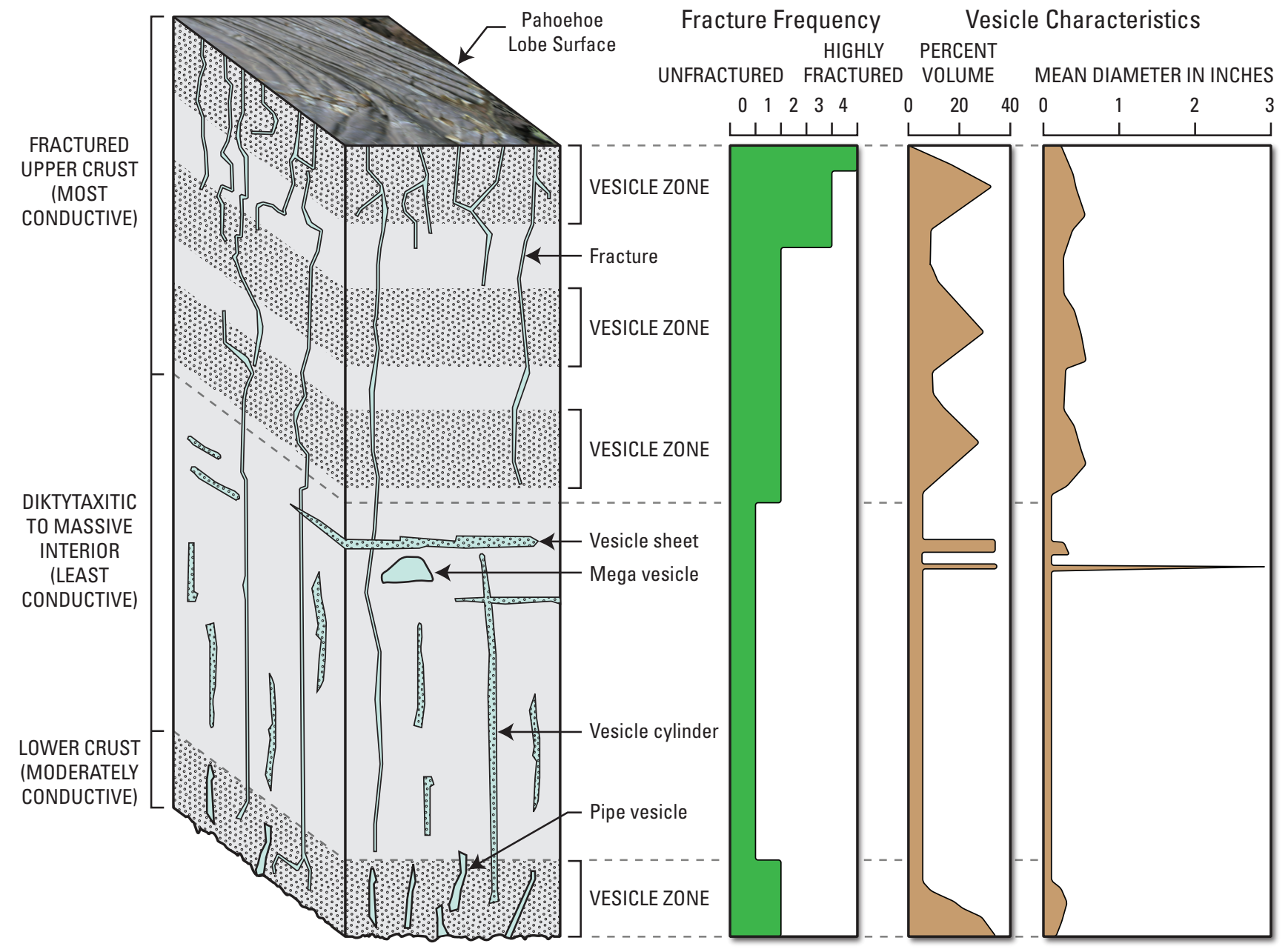

Figure 3. Idealized typical olivine tholeiitic pahoehoe basalt flow (modified from Self and others, 1998, fig. 3, p. 90). The basalt flow is divided into three sections on the basis of vesicle characteristics and fracture frequency. Hydraulic conductivity is highest for the Fractured Upper Crust, moderate for the Lower Crust, and lowest for the Diktytaxitic to Massive Interior. The photograph of the pahoehoe lobe surface is courtesy of Scott Hughes, Idaho State University, Pocatello, Idaho. 


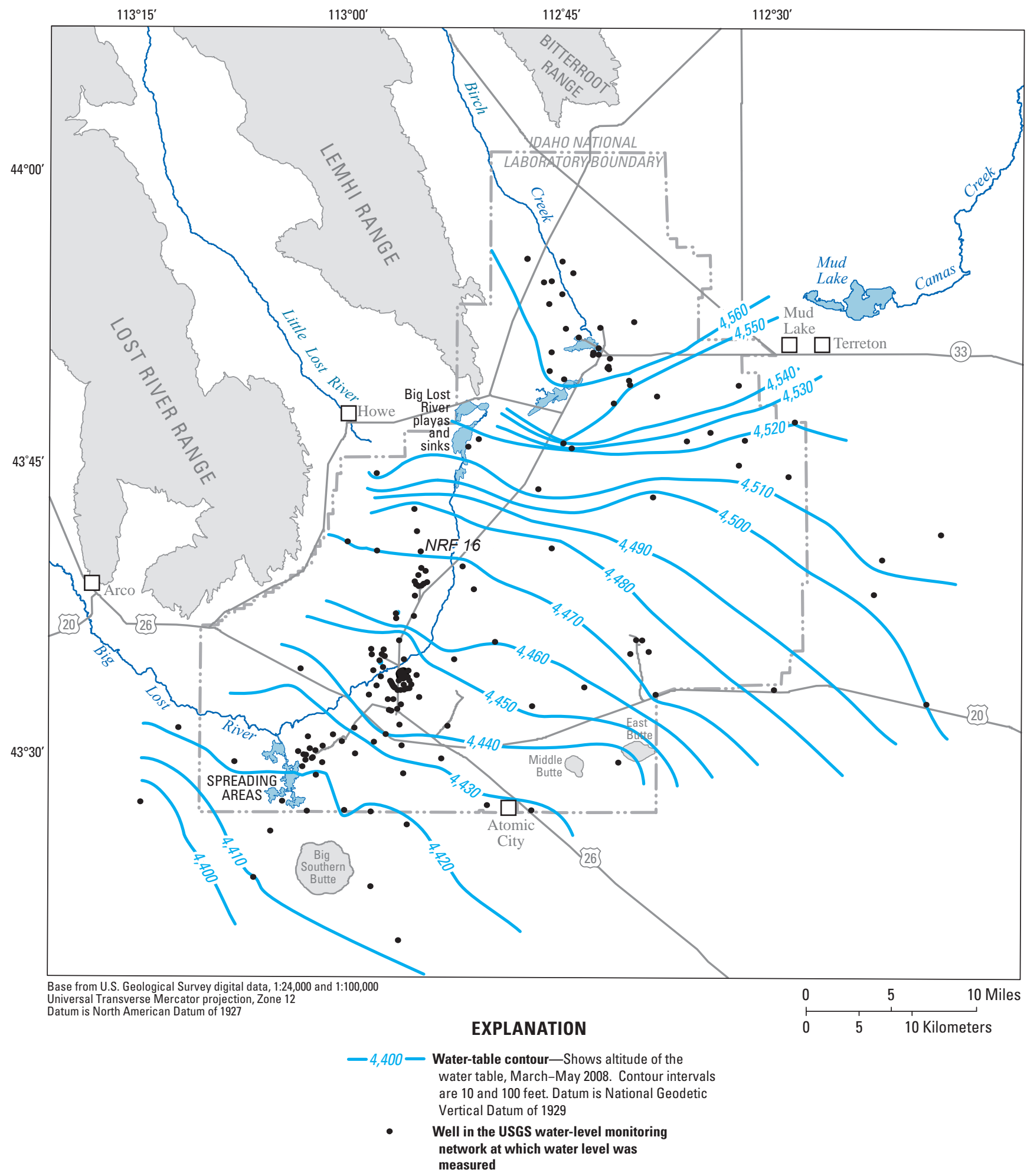

Figure 4. Water-table contours, measured during March-May 2008, and monitoring wells at and near the Idaho National Laboratory, Idaho. 


\section{Drilling and Borehole Construction Methodology}

The location and final design for the new monitoring well, NRF-16, was determined by NRF (Kelly Willie, Bechtel/ Bettis Corp., written commun., July 15, 2008). Drilling, well construction, and hydraulic testing by the USGS INL Project Office took place August 3, 2009, through November 24, 2009. All activities were performed in accordance with the USGS INL Site Safety Plan and the NRF monitoring well specification document(s) (Kelly Willie, Bechtel/Bettis Corp., written commun(s)., July 15, 2008). Additionally, the USGS performed and documented regular safety inspections and safety briefings. Material Safety Data Sheet (MSDS) files for all chemicals used during drilling are included in appendix A.

Prior to drilling startup, a staging area was established for cleaning and decontamination of equipment. All drill stem, casing components, stainless pipe, screen(s), pump, and drilling equipment were cleaned using a Hotsy ${ }^{\mathrm{TM}}$ HSS-80389E diesel pressure washer. Protective tarps were placed under the drill rig and equipment was checked on a daily basis for signs of hydraulic leaks. No reportable spills or leaks occurred while drilling at this location.

\section{NRF-16 Drilling Methods}

Well NRF-16 was continuously cored using a Christensen ${ }^{\mathrm{TM}}$ CS 1500 rotary drilling rig and PQ-size coring system, where PQ refers to core rod sizing (pipe size about 4.6 in. outside diameter and drill bit size about $4.8 \mathrm{in}$.). The coring system uses Crisdrill ${ }^{\mathrm{TM}}$ diamond drill bit(s), core catchers, latch assembly, and dual retrieval systems (fig. 5). Core was retrieved in 5-ft long sections using a wireline latching mechanism (quadlatch) located at the top of the core barrel assembly. Once removed from the borehole, core was marked for vertical direction and depth in the field before boxing. Core was photographed and archived at the INL Lithologic Core Storage Library (Davis and others, 1997), operated by the USGS INL Project Office, located at Central Facilities Area (CFA).

Reaming and setting the surface casing was performed using a rotary drill rig mounted to a Peterbilt ${ }^{\mathrm{TM}}$ diesel truck. A hydraulically operated downhole hammer was used to advance the surface casing through surficial alluvium. Tricone drill bits were used to ream out sections of the borehole prior to setting the casing and screen. To straighten deviated and fractured borehole sections, a 21-ft stabilizer was run with a tri-cone reaming bit. This technique prevented ledges in fractured sections from hanging the casing during lowering.

The cementing technique requested by NRF was used to pressure a grout slurry down the inside of the $7 \mathrm{in}$. casing with return coming up the outside of the casing. Bridging problems prevented the grout slurry from moving up the outside of the casing. After several attempts to move the casing, an alternate approach using a $1 \mathrm{in}$. tremie line to pump the grout slurry between the annular space was successful based on examination of geophysical information. Displaced cement grout inside of the 7 in. casing had to be drilled out using a rotary tri-cone bit before advancing the borehole.

Drilling fluids included water and pressurized air, which were supplied using a Sullair ${ }^{\mathrm{TM}}$ diesel air-compressor, equipped with an air filtration system. Air and water mist were continuously used during coring and reaming of NRF 16. Drill water was transported from well USGS 17 using a 3,000 gal capacity water truck. Water from well USGS 17 was used because the well is upgradient from the NRF, the water has small cation and anion concentrations (Bartholomay, Knobel, Tucker, and others 1997a), and because the water shows no constituents of concern. During drilling, the rate of water usage ranged from 2 to $4 \mathrm{gal} / \mathrm{min}$ and air pressures ranged from 105 to $350 \mathrm{lb} / \mathrm{in}^{2}$.

\section{NRF-16 Construction}

Well NRF-16 was continuously cored to a depth of $425 \mathrm{ft}$ BLS from August 10, 2009, through August 25, 2009; the local water table is near $360 \mathrm{ft}$ BLS. No perched water was encountered during coring and sediment layers that were recovered were described as mostly dry.

After coring was completed, geophysical logs were collected through drill rod and water samples were collected. Core, geophysical, and water chemistry data indicated the aquifer at this location was favorable for installation of a replacement monitoring well. Core material and geophysical data were used to approximate aquifer productivity and to determine the location for setting the screen material. Water samples were collected at about $408 \mathrm{ft}$ BLS on August 26, 2009. Final construction of well NRF-16 began on September 1, 2009.

Prior to reaming, a 10-in. diameter surface casing was set at about $15 \mathrm{ft}$ BLS. Attempts to drill a 12-in. borehole and lower the casing failed, so a hydraulically operated casing hammer was mounted to the Peterbilt ${ }^{\mathrm{TM}}$ drill rig to drive the casing through surficial sediment. Once the casing was set, the casing hammer was removed and drilling continued.

Borehole NRF-16 was reamed using a 9.25-in. tungsten and carbide tricone bit with 4.75-in. tungsten and carbide pilot bit from about 15 to $341 \mathrm{ft}$ BLS from September 2, 2009, through September 23, 2009. A second attempt to ream the borehole using a $9.25 \mathrm{in}$. tricone equipped with a 21-ft stabilizer bit took place September 28, 2009, through October 5, 2009. Additional time was spent running a large stabilizer bit because the first attempt to set 7 -in. casing was problematic and the borehole had to be re-reamed due to borehole collapsing conditions. 


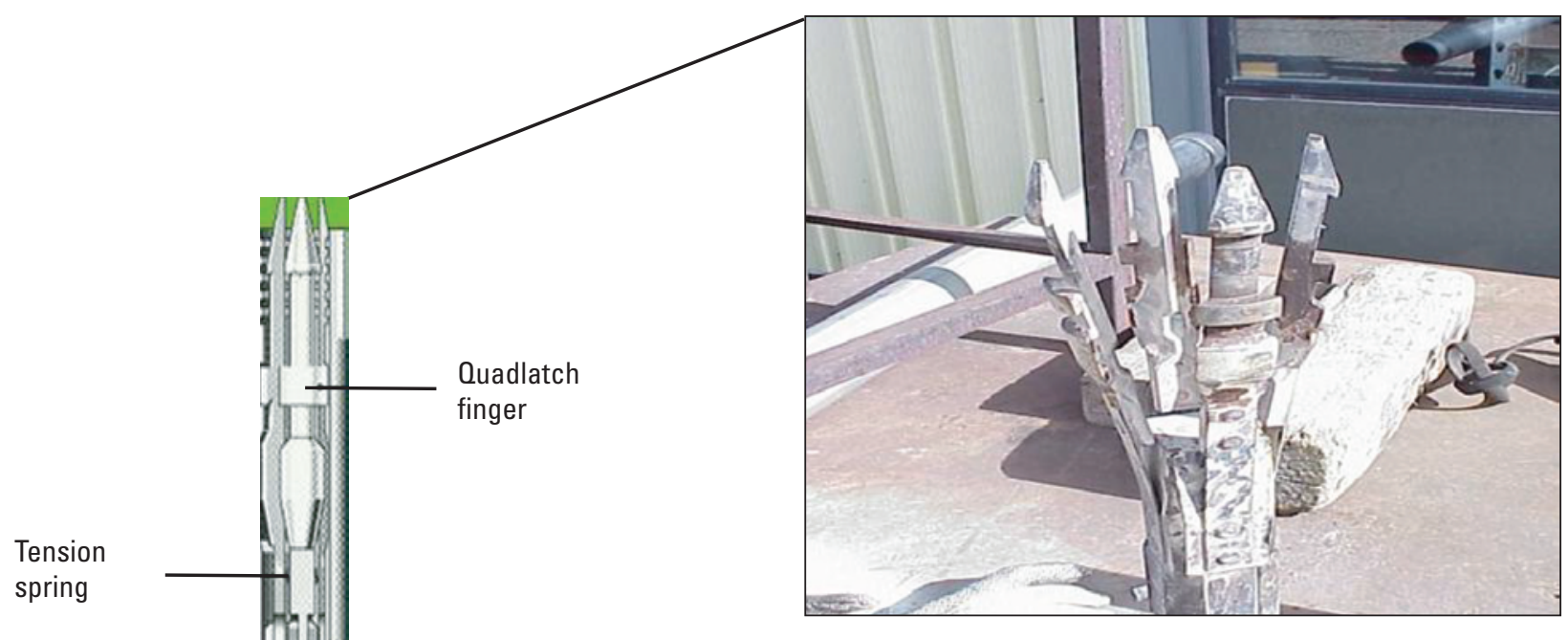
A. Quadlatch assembly

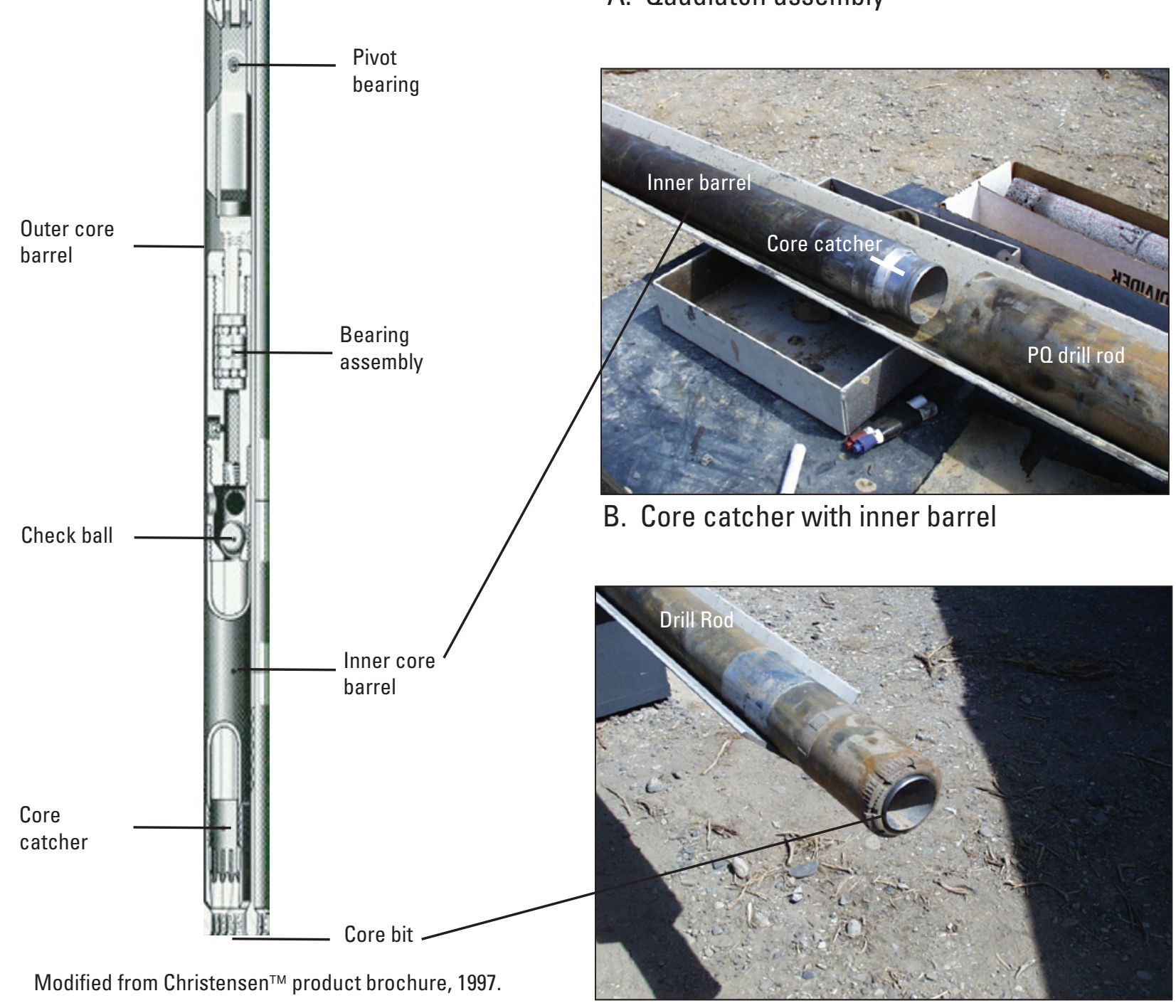

C. Core bit

Figure 5. PQ-size coring system, similar to one used for coring well NRF-16, Naval Reactors Facility, Idaho National Laboratory, Idaho. 
A 7-in. outside diameter carbon steel casing was buttwelded and placed $341 \mathrm{ft}$ BLS October 6, 2009, to October 8, 2009 , then a pre-mixed grout slurry was used to seal the annular space between the 7-in. casing and 9.25-in. borehole October 13, 2009 to October 20, 2009. The grout slurry could not be continuously injected because transportation to borehole NRF-16 was limited to one load per day due to poor weather and road conditions. Initial attempts to pressure grout slurry inside of the 7-in. casing with grout return coming up the outside of the casing were limited to approximately $2 \mathrm{yd}^{3}$ before the grout slurry began filling the inside of the 7-in. casing due to bridging between the annular space. A decision was made to halt the grouting once the grout slurry level inside of the 7-in. casing reached about $100 \mathrm{ft}$ BLS. Attempts were made to unbridge the grout slurry by moving the casing; however, the casing was raised to approximately $339 \mathrm{ft}$ BLS before grout slurry cured and locked the casing in place at about $339 \mathrm{ft}$ BLS. A second method using a 1-in. tremie line to pump grout slurry between the annular space and seal the 7-in. casing in place was successful. Approximately $29 \mathrm{yd}^{3}$ of grout slurry was pumped through tremie line until grout reached the top of the 7 -in. casing. A total of $31 \mathrm{yd}^{3}$ of Portland Type II grout slurry ( 20 parts cement 1 part bentonite) were used to seal the annular space between the casing and borehole.

Cured grout slurry inside the 7 -in. casing was drilled out from 100 to $339 \mathrm{ft}$ BLS using 6-in. tungsten and carbide tricone bit from October 26 to October 28, 2009. Drilling was halted near $339 \mathrm{ft}$ BLS and cuttings and debris were flushed with air and water to land surface from near the bottom of the 7-in. casing for several hours before advancing. The borehole was reamed from 339 to $425 \mathrm{ft}$ BLS using the same 6-in. tungsten and carbide tricone bit on October 29, 2009. A downhole video log taken of the borehole on October 30, 2009 revealed a rock bridge near $381 \mathrm{ft}$ BLS and a second attempt was made to ream the borehole.

A larger, 6.25-in. tungsten and carbide tri-cone drill bit was run November 2, 2009 from 339 to $425 \mathrm{ft} \mathrm{BLS}$. After removing the reaming bit, a downhole video log was run and revealed the borehole was in good condition and open to $422 \mathrm{ft}$ BLS (appendix B, NRF16 OpenHole.flv), with sluff from 422 to $425 \mathrm{ft}$ BLS. Open hole geophysical logs were run on November 4, 2009 prior to setting the final screen. Screen, casing, and components used for hydraulic pump testing were pressure washed on November 12, 2009.

A wire-wrap well screen and screen blank were placed in well NRF-16 on November 13, 2009 using the Christensen ${ }^{\mathrm{TM}}$ CS 1500 core rig (fig. 6). Drill rod was used to lower the screen assembly to the bottom of the borehole on a reverse threaded casing adapter. The casing adapter was equipped with rubber wipers to seal the screen and prevent movement. After the drill rod was removed from the well a borehole video was run to examine the screen (appendix B, NRF16 Screen.flv). The final monitoring well configuration includes: (1) 6.5-in. figure k-packer with rubber wipers by 5-in. pipe size from 300 to $302 \mathrm{ft} \mathrm{BLS,} \mathrm{(2)} \mathrm{5-in.} \mathrm{pipe} \mathrm{size} \mathrm{(PS)} 304$ stainless steel (SS) casing extending from 302 to $362 \mathrm{ft}$ BLS, and (3) 5-in. PS 304 SS wire wrap well screen equipped with a bottom plug extending from 362 to $422 \mathrm{ft}$ BLS (ig. 6). Sluff from 422 to $425 \mathrm{ft}$ BLS, prevented setting the screen deeper than $422 \mathrm{ft}$ BLS. The final monitoring well completion for NRF-16 is summarized in table 1.

A temporary pump, discharge line, and water level measuring line were set in order to run hydraulic pumping tests during November 16 to 17,2009 . Once hydraulic testing was complete, the temporary pump and measurement line were removed and a final downhole video log was run to examine the condition of the well prior to setting the final pump and water level measuring line.

The final monitoring well was configured with a Grundfos $^{\text {TM }}$ 5-horse power submersible pump, 4-wire 7 gauge pump wire, 1.25- in. SS discharge line, and 1-in. SS water level line on November 23, 2009 (fig. 6). The pump intake was set at about $402 \mathrm{ft}$ BLS and the 1-in. measuring line was capped at about $390 \mathrm{ft}$ BLS. Surface completion consisted of a 4-ft concrete pad complete with a brass-survey marker, steel impingement guard posts around the well, and a locking well head. Well drilling equipment was removed on November 24, 2009.

Table 1. Location and completion information for monitoring well NRF-16, Naval Reactors Facility, Idaho National Laboratory, Idaho.

[Location of well shown in figure 1; diagram of well shown in figure 6. Local name is the local well identifier used in this study. Site identifier is the unique numerical identifier used to access well data (http://waterdata.usgs.gov/ nwis). Abbreviations: NAD 27, North American Datum of 1927; NGVD 29, National Geodetic Vertical Datum of 1929; NRF, Naval Reactors Facility]

\begin{tabular}{|r|l|}
\hline Local name & NRF-16 \\
\hline Site identifier & 434018112545101 \\
\hline Longitude & $112^{\circ} 54^{\prime} 51.8^{\prime \prime}$ (NAD 27) \\
\hline Latitude & $43^{\circ} 40^{\prime} 18.5^{\prime \prime}$ (NAD 27) \\
\hline Land surface elevation & 4,833 feet (NGVD 29) \\
\hline Aquifer thickness & $\begin{array}{c}847 \text { feet, estimated distance between } \\
\text { land surface and bedrock }\end{array}$ \\
\hline Drilled borehole depth & 425 feet below land surface \\
\hline Completion depth & 422 feet below land surface \\
\hline Borehole diameter & 6.25 inches \\
\hline Casing diameter & 5 inch inside diameter \\
\hline Top of screen & 362 feet below land surface \\
\hline Bottom of screen & 422 feet below land surface \\
\hline Depth to water & $\begin{array}{c}359.96 \text { feet below land surface, } \\
\text { measured November 16, 2009, at } \\
10: 25 \text { AM pre-pumping }\end{array}$ \\
\hline & \\
\hline
\end{tabular}




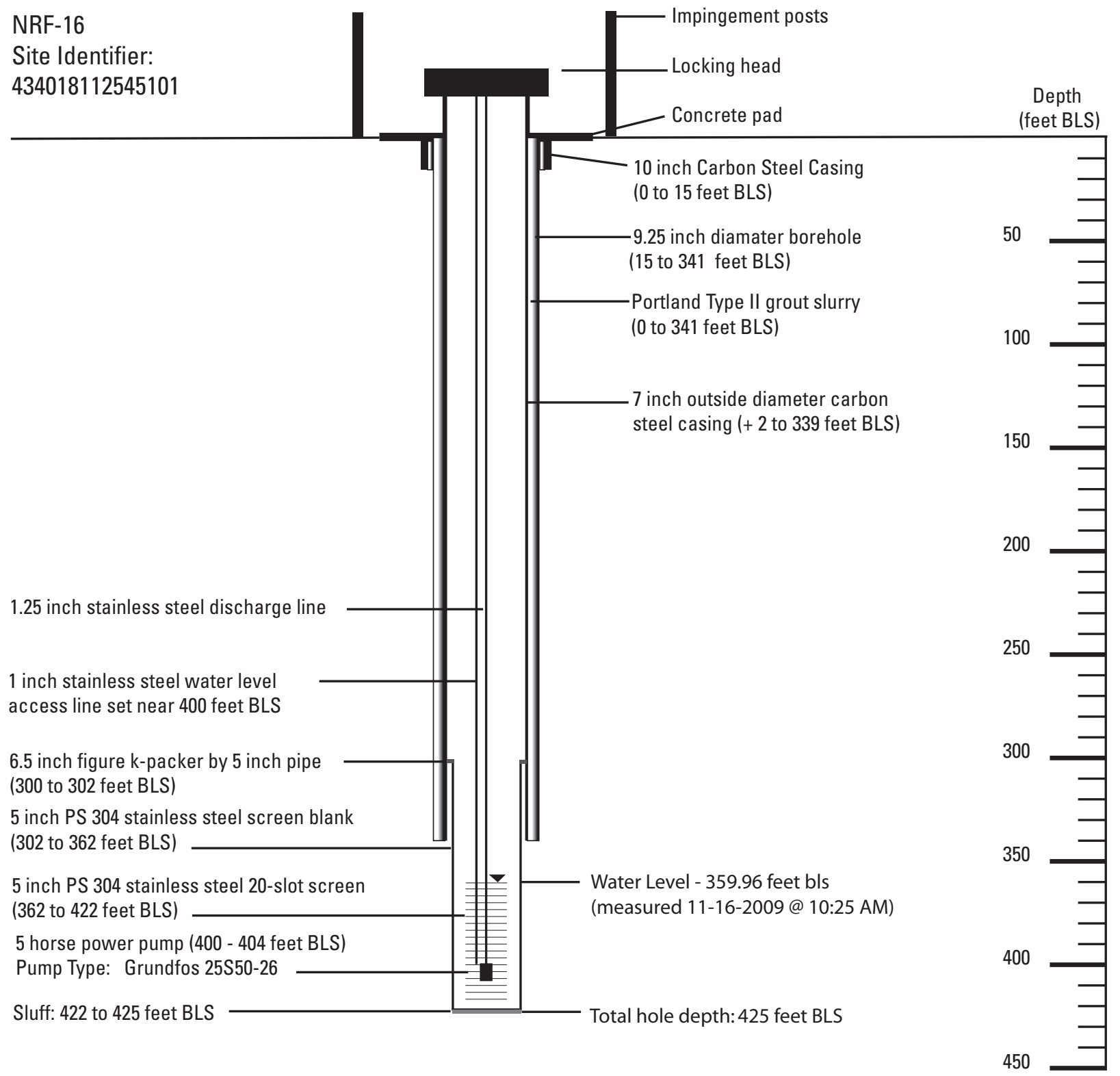

Figure 6. Final design of monitoring well NRF-16, Naval Reactors Facility, Idaho National Laboratory, Idaho.

\section{Geologic and Geophysical Descriptions}

Analysis of core material collected during coring of NRF-16 was used to provide a general geologic description along with geophysical data that were collected after completion of coring and completion of the final borehole.
Borehole geophysics included natural gamma, neutron, gamma-gamma dual density, and caliper logs. Gyroscopic deviation surveys were run to determine direction and magnitude of borehole deviation. Borehole video surveys were run to look at the condition of the drilled borehole and final monitoring well. Geophysical data were displayed using WellCAD ${ }^{\mathrm{TM}}$ software and data were used to describe geologic and hydrologic features. 


\section{Geologic Descriptions}

Sparsely vegetated eolian deposits were detected in the uppermost geologic unit in NRF-16. Surficial sediments were $9.6 \mathrm{ft}$ thick and were composed of silt to fine sand loess deposits, yellowish brown in color.

Five sediment layers, excluding surficial sediment, were detected in NRF-16. Sediment layers primarily are composed of fine to course alluvial sand; layers range from 0.2 to $6 \mathrm{ft}$ thick. Top of sediment layers occur near 15, 65, 122, 209, and $336 \mathrm{ft}$ BLS. No sediment was detected within the screened interval (362-422 ft BLS).

Olivine tholeiite basalt comprised 96 percent of the unsaturated zone and 100 percent of the saturated zone in NRF-16. Approximately 22 individual basalt flows were observed at NRF-16 ranging in thickness from 2 to $65 \mathrm{ft}$, based on visual inspection of core and geophysical data. Basalt varied from highly fractured to dense, with high-to-low vesiculation and aphanitic-to-fine grained texture, and was medium to-dark gray in color.

\section{Geophysical Logging}

Wireline geophysical logs were run during several phases of the NRF-16 construction; logs were collected by the USGS after completion of coring and completion of the final borehole (table 2). Geophysical data were collected using Century ${ }^{\mathrm{TM}}$ logging equipment and data files were processed using WellCAD ${ }^{\mathrm{TM}}$ analytical software. Additionally, borehole video logs were recorded using a Laval ${ }^{\mathrm{TM}} \mathrm{R}-2000$ downhole video system. Digital video files are included in appendix B. Raw borehole geophysical data for NRF-16 are available upon request in Log ASCII Standard (LAS) format by contacting the USGS INL Project Office.

Natural gamma, caliper, neutron, gamma-gamma dual density, temperature, specific conductivity, gyroscopic deviation, and borehole video logs were all collected during various drilling stages at NRF-16. Temperature and conductivity logs were collected but are not presented in this report because they were collected following drilling and were not representative of in situ aquifer conditions. A composite of natural gamma, caliper, neutron, and gamma-gamma dual density logs along with general lithology from land surface to total depth are included in figure 7.

Table 2. Summary of geophysical and video logs collected at well NRF-16, Naval Reactors Facility, Idaho National Laboratory, Idaho.

[Abbreviations: NRF, Naval Reactors Facility; BLS, below land surface; PQ, core rod sizing (pipe size about 4.6 in. outside diameter and drill bit size about 4.8 in. diameter)]

U.S. Geological Survey geophysical logging files

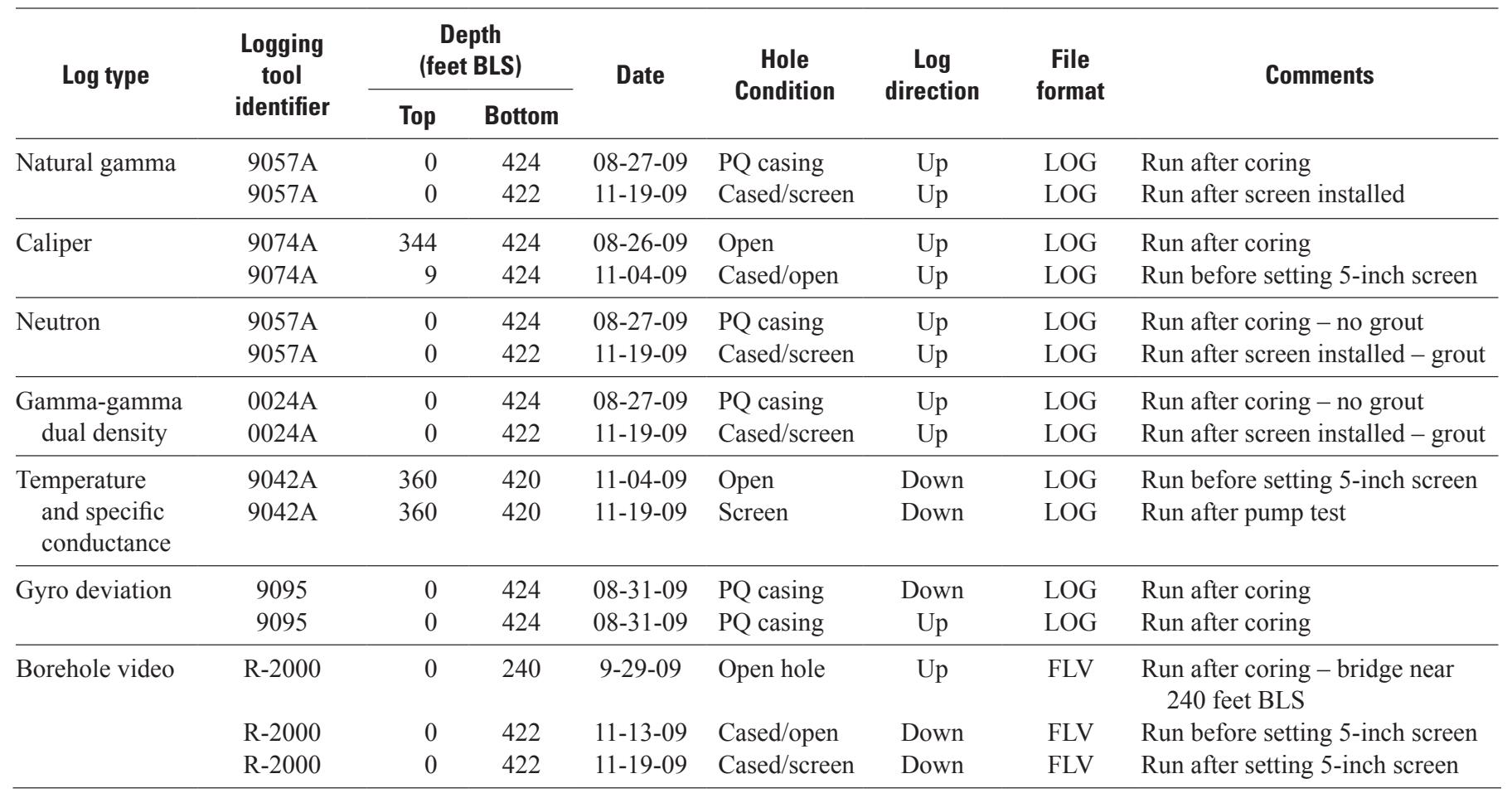




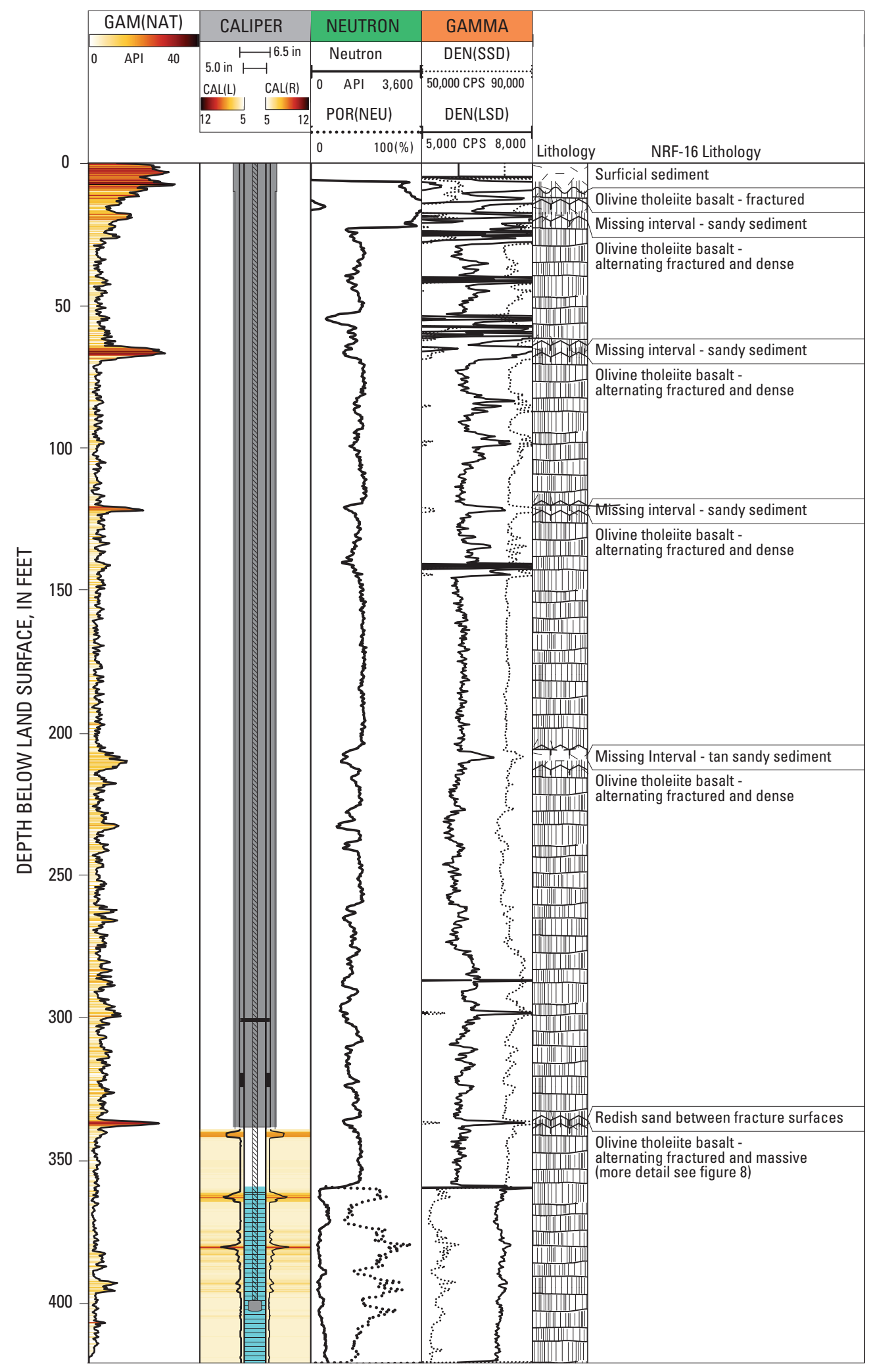

\section{EXPLANATION}

\section{Definition of terms}

GAM(NAT) - natural gamma radiation NEUTRON - hydrogen index POR(NEU) - liquid-filled porosity DEN(SSD) - short-spaced density DEN(LSD) - long-spaced density CAL(L) - left side caliper CAL(R) - right side caliper API - American Petroleum Institute CPS - counts per second

Figure 7. Geophysical and lithologic logs run from total depth to land surface for borehole NRF-16, Naval Reactors Facility, Idaho National Laboratory, Idaho. 


\section{Natural Gamma Logs}

Natural gamma logs record gamma radiation emitted by naturally occurring radioisotopes and commonly are used at the INL to identify sedimentary layers in boreholes and distinguish between basalt flows that have differences in potassium-40. Some examples of naturally occurring radioisotopes in the eastern SRP basalts are potassium-40, bismuth-214, lead-214, actinium-228, thorium-232, and uranium-238 (Barraclough and others, 1976). The gamma detector measures total gamma radiation without distinguishing between individual contributions of the various isotopes.

Natural gamma logs were collected after coring and after completion of the final monitoring well. The natural gamma log taken after completion of coring on August 27, 2009, is shown in figure 7 . The log depicts a $9.6 \mathrm{ft}$ surficial sediment layer and confirms the tops of five sediment layers identified from the borehole core. Several zones show an increase in natural gamma radiation, which may be indicative of clay deposits within fractures. A borehole video survey taken November 13, 2009 displays this phenomenon near $395 \mathrm{ft}$ BLS (appendix B, NRF16 OpenHole.flv).

\section{Caliper Logs}

The caliper tool provides a continuous log of the drill-hole diameter by using three extendable spring loaded arms, capable of detecting changes in borehole diameter of 0.15 in. or greater. Changes in borehole diameter, detected by the amount of deflection of the caliper arms, are recorded as the caliper tool is brought up from the bottom of the borehole. Caliper data was used to depict fractured and dense sections within NRF-16.

Caliper logging was done after coring and again after reaming NRF-16 in open borehole conditions from approximately 340 to $424 \mathrm{ft}$ BLS. Unstable conditions prevented a continuous caliper profile for the entire borehole. Figure 7 shows the caliper trace taken November 4, 2009 following reaming. The caliper log, along with visual inspection of the core, depicts fracture and vesiculated sections extending from about 362 to $366 \mathrm{ft} \mathrm{BLS,} 375$ to $387 \mathrm{ft}$ BLS, 392 to $398 \mathrm{ft}$ BLS, and 403 to $406 \mathrm{ft}$ BLS.

\section{Neutron Logs}

Neutron measurements are used as a general indicator of hydrogen content, and when combined with natural gamma logs for sediment location, can be used to identify perched water zones in the unsaturated zone. The neutron log records the continuous measurement of the induced radiation produced by bombarding surrounding media (casing, formation, and fluid) with fast neutrons (energies greater than $10^{5} \mathrm{eV}$ ) from a sealed neutron source, which collide with surrounding atomic nuclei until they are captured (Keys, 1990, section 5, p. 95). The neutron tool used by the USGS INL Project Office has an americium/beryllium neutron source, and a Helium-3 detector that counts slow (thermal) neutrons (those that have energies less than $0.025 \mathrm{eV}$ ).

Neutron logs were run after completion of coring and after the final monitoring well screen was placed in NRF-16. A neutron trace (fig. 7) was made on August 27, 2009, immediately following the initial coring to $425 \mathrm{ft} \mathrm{BLS}$ and was examined for evidence of perched water. The neutron log shows elevated hydrogen near $55 \mathrm{ft}$ BLS, just above a sediment layer about $65 \mathrm{ft}$ BLS; however, borehole video logs run after removing the drill rod revealed no evidence of perched water (appendix B, NRF16 PerchedWater.flv). This zone, near $55 \mathrm{ft}$ BLS, may have been influenced by drilling water or antecedent moisture conditions.

Neutron logs, examined for the section of aquifer extending from 360 to $424 \mathrm{ft}$ BLS, were used to identify areas of higher and lower hydrogen content in NRF-16 (fig. 8). A horizontal gradient, ranging from red (higher hydrogen content) to white (lower hydrogen content), was applied to neutron logs in WellCAD ${ }^{\mathrm{TM}}$ and used to infer areas of fractured and dense basalt; the neutron log shows excellent correlation with the drill core lithology log (fig. 8). Areas of low hydrogen correlate with areas of dense and massive basalt and areas of higher hydrogen content correlate with areas of fractured and vesicular basalt. Based on basalt-hydrogen correlations, neutron logs show evidence for fractured and vesicular basalt, indicative of water producing zones, from 362 to $365 \mathrm{ft}$ BLS, 375 to $388 \mathrm{ft} \mathrm{BLS,} 392$ to $398 \mathrm{ft} \mathrm{BLS}$, and 403 to $406 \mathrm{ft}$ BLS in NRF-16. 


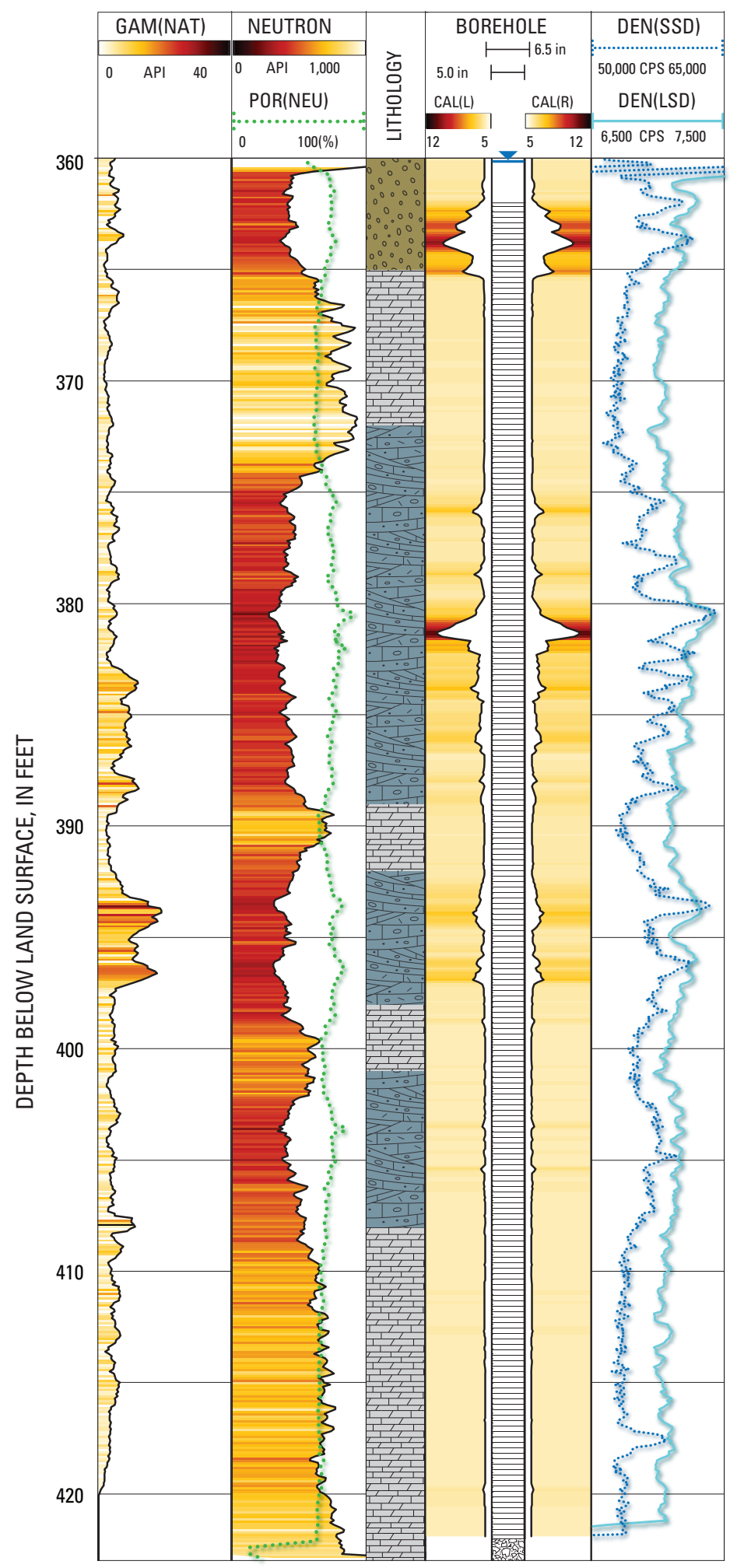

\section{EXPLANATION}

$\because \because$ Vesicular basalt

Dense basalt

Fractured and vesicular basalt

Well completion

| Well casing

$\Longrightarrow$ Screened interval

Loose rocks and sediment

Water level prior to pumping

\section{Definition of terms}

GAM(NAT) - natural gamma radiation NEUTRON - hydrogen index POR(NEU) - liquid-filled porosity DEN(SSD) - short-spaced density DEN(LSD) - long-spaced density CAL(L) - left side caliper $\mathrm{CAL}(\mathrm{R})$ - right side caliper API - American Petroleum Institute CPS - counts per second

Figure 8. Geophysical and lithologic logs with focus on depths 360-424 feet below land surface for NRF-16, Naval Reactors Facility, Idaho National Laboratory, Idaho. 


\section{Gamma-Gamma Dual Density Logs}

The gamma-gamma dual density log, also known as the induced gamma-density log, measures bulk density of the formation in the immediate vicinity of the borehole. Two separately-spaced detectors record induced gamma-radiation intensity from an encapsulated radioactive source after it is backscattered or absorbed in a drill hole, borehole fluid, or surrounding media (Chase and others, 1964). Very dense materials increase scatter, and cause increased absorption of gamma radiation; the increased absorption of gamma radiation results in fewer particles returning to the detector. The opposite is true for fractured and low density materials. The induced gamma signal is attenuated in direct proportion to the bulk density of a formation.

Gamma-gamma dual density logs were run after completion of coring and after completion of the final monitoring well. The gamma-gamma trace taken August 27, 2009, immediately following the initial coring to $425 \mathrm{ft}$ BLS is shown in figure 7. Density logs were used to reference areas of dense as opposed to fractured basalt and show excellent correlation with the lithology log (fig. 7). Density logs confirm that fractured basalt occurred between the intervals 362 to $365 \mathrm{ft}$ BLS, 375 to $388 \mathrm{ft} \mathrm{BLS}, 392$ to $398 \mathrm{ft} \mathrm{BLS}$, and 403 to $406 \mathrm{ft}$ BLS in NRF-16.
Gamma-gamma dual density logs also were used to investigate the effects of grouting. Logs taken August 27, 2009, and November 19, 2009, were examined to determine the extent of the grout seal from land surface to $339 \mathrm{ft} \mathrm{BLS}$ (fig. 9). A slight drop in density response occurs near $301 \mathrm{ft}$ BLS where the top of the well screen lies inside of the 7 in. casing. Both gamma short-spaced density (SSD) and gamma long-spaced density (LSD) detectors show consistent readings which indicate the annular seal is present from land surface to $339 \mathrm{ft}$ BLS (ig. 9).

\section{Gyroscopic Deviation Survey}

A borehole gyroscopic-deviation survey was run after completion of coring on August 31, 2009. The gyroscopic-deviation survey was done to determine whether well NRF-16 would meet NRF specification(s): (1) vertical projection of the borehole from land surface to bottom of the borehole does not deviate more than $20 \mathrm{ft}$ in any direction, and (2) measured length of the borehole does not exceed the vertical distance between the top and bottom of the well by more than 2 percent (NRLFO/IFO, written commun., July 25, 2008). A summary of borehole deviation listings referenced to $400 \mathrm{ft}$ BLS is presented in table 3. Data indicate a $11.45 \mathrm{ft}$ horizontal deviation from vertical with 1.6 degree deviation from vertical, which are within NRLFO/IFO monitoring well specifications.

Table 3. Gyroscopic deviation survey summary from well NRF-16, Naval Reactors Facility, Idaho National Laboratory, Idaho.

[Survey performed using 9095 Century ${ }^{\mathrm{TM}}$ logging tool. Reference sighting azimuth was set to 20 degrees, magnetic declination 13.9 degrees, and sighting and drift stations were taken from top of 4.9-inch casing. Abbreviations: NRF, Naval Reactors Facility; BLS, below land surface]

\begin{tabular}{|c|c|c|c|c|}
\hline $\begin{array}{c}\text { Borehole } \\
\text { name }\end{array}$ & $\begin{array}{l}\text { Horizontal deviation } \\
\text { from vertical taken at } \\
400 \text { feet BLS } \\
\text { (feet) }\end{array}$ & $\begin{array}{c}\text { Degrees deviation } \\
\text { from vertical taken at } \\
400 \text { feet BLS }\end{array}$ & $\begin{array}{l}\text { True drillhole } \\
\text { length at } \\
400 \text { feet BLS } \\
\text { (feet) }\end{array}$ & $\begin{array}{l}\text { Drillhole azimuth } \\
\text { at } 400 \text { feet BLS } \\
\text { (degrees) }\end{array}$ \\
\hline NRF-16 & 11.45 & 1.6 & 399.82 & 76 \\
\hline
\end{tabular}




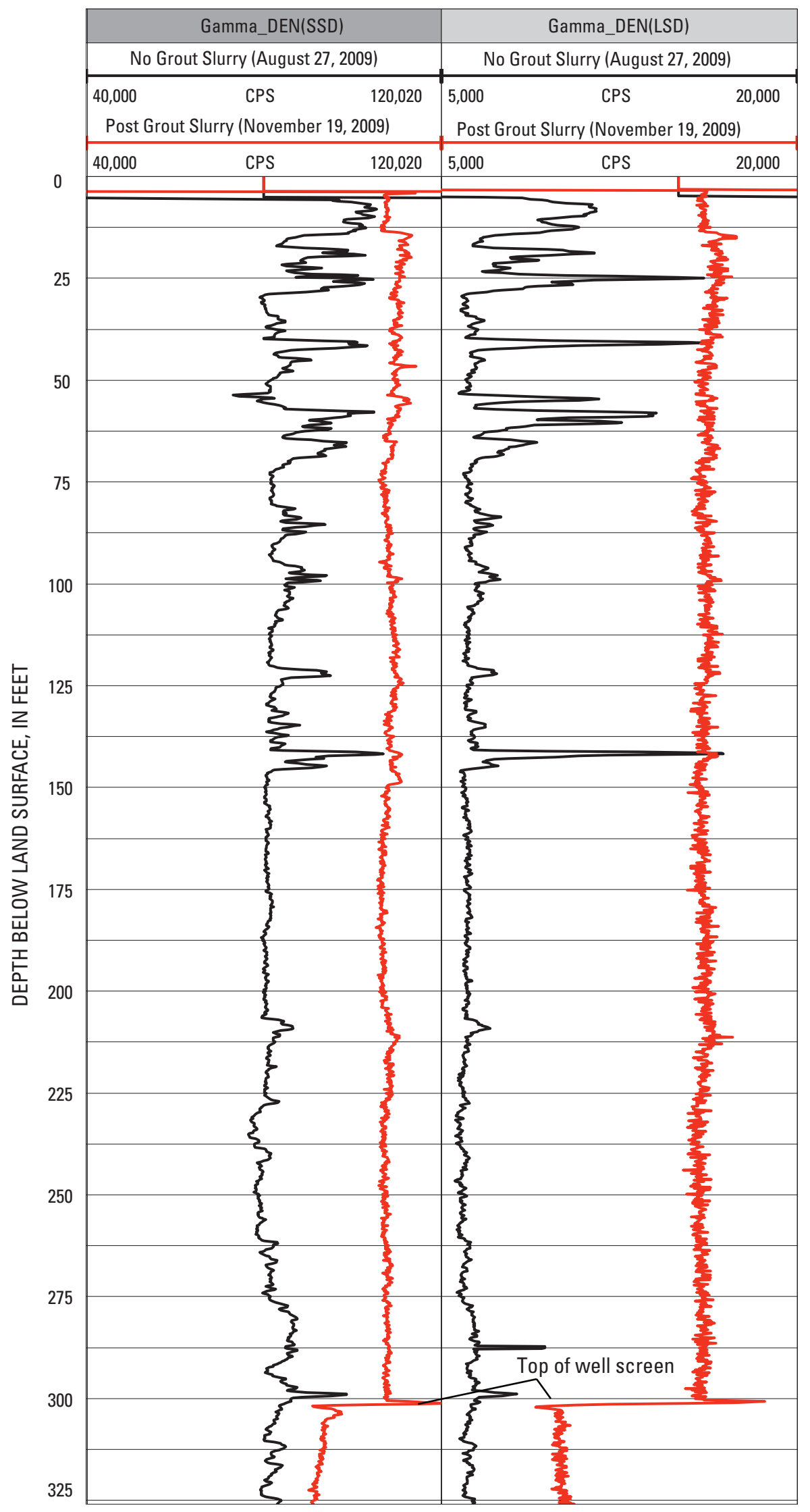

\section{EXPLANATION}

\section{Definition of terms}

DEN(SSD) - short-spaced density DEN(LSD) - long-spaced density 


\section{Hydrologic Description}

The pre- and post-pumping test data were collected and relative trends were analyzed. Prolonged pumping tests confirmed that well NRF-16 met or exceeded sustained discharge rates of $15 \mathrm{gal} / \mathrm{min}$. The pumping also removed any effects of drilling fluid introduced during construction of NRF-16.

\section{Perched Water}

No perched water was encountered during drilling activities and this was further confirmed through examination of geophysical and video logs. One area of elevated moisture was noted near $55 \mathrm{ft} \mathrm{BLS}$, but the source could not be determined (drilling or antecedent moisture). Air and water circulation during drilling may have forced small amounts of water to settle out near $55 \mathrm{ft}$ BLS.

\section{Aquifer Test Procedures}

During November 16-17, 2009 two single-well aquifer tests were conducted and fluid pressure head, barometric head, fluid temperature, and air temperature were measured continuously. The fluid pressure head, $\Psi_{w}$, and temperature were measured with a Solinst Levelogger ${ }^{\mathrm{TM}}$, a self contained water level and temperature datalogger suspended on a wireline below the water table (fig. 10). The barometric head, $\Psi_{\text {atm}}$, and temperature were measured with a Solinst Barologger ${ }^{\mathrm{TM}}$, a self contained atmospheric pressure and temperature datalogger suspended on a wireline above the water table (fig. 10). Figure 11 shows the measurements through time. The pressure head was compensated for changes in atmospheric pressure (fig. 11) and calculated using the following equation:

$$
\psi=\psi_{w}-\psi_{\text {atm }},
$$

where

$\psi$ is compensated pressure head,

$\psi_{w}$ is fluid pressure head, and

$\psi_{\text {atm }}$ is barometric head.

Recovery data were collected but not analyzed.

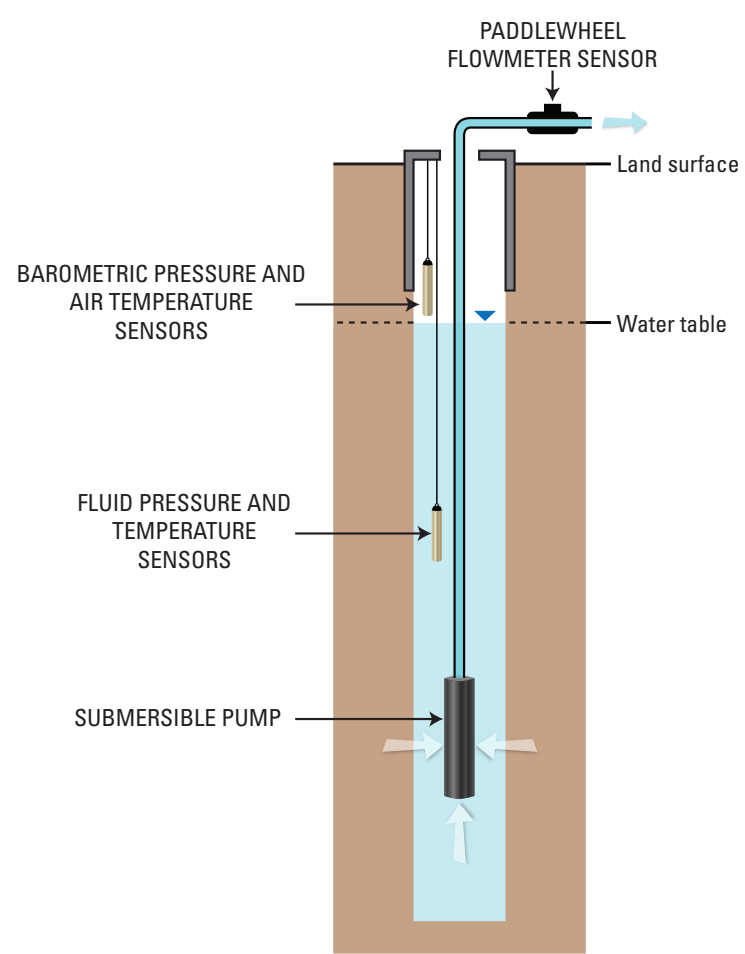

Figure 10. Idealized placement of sensor during the aquifer tests, Naval Reactors Facility, Idaho National Laboratory, Idaho. Not to scale.

The flow rate, $Q$, associated with well discharge was monitored periodically using a Blue-White ${ }^{\mathrm{TM}} \mathrm{F}-2000$ paddlewheel flowmeter sensor (fig. 10). Measured flow rates (fig. 12) remained relatively constant throughout the tests at $30 \mathrm{gal} / \mathrm{min}$. Estimates of the average pumping rate during the first and second aquifer tests were 29.9 and $30.0 \mathrm{gal} / \mathrm{min}$, respectively. Discharges ranged from 29.3 to $30.5 \mathrm{gal} / \mathrm{min}$. 


\section{NRF-16 AQUIFER TESTS}
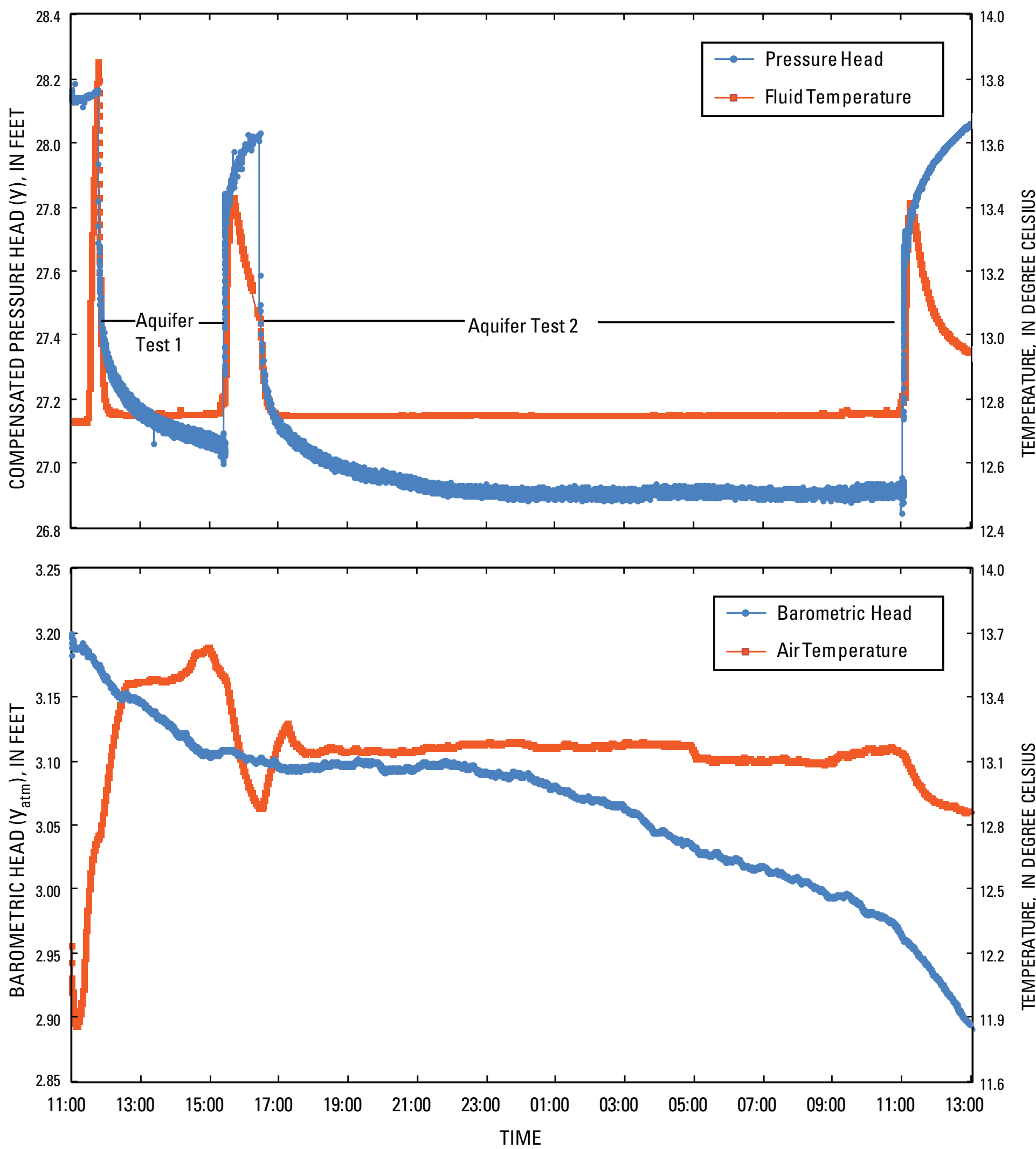

Figure 11. Changes in compensated pressure head, barometric head, fluid temperature, and air temperature through time during aquifer tests, Naval Reactors Facility, Idaho National Laboratory, Idaho, November 16-17, 2009. 


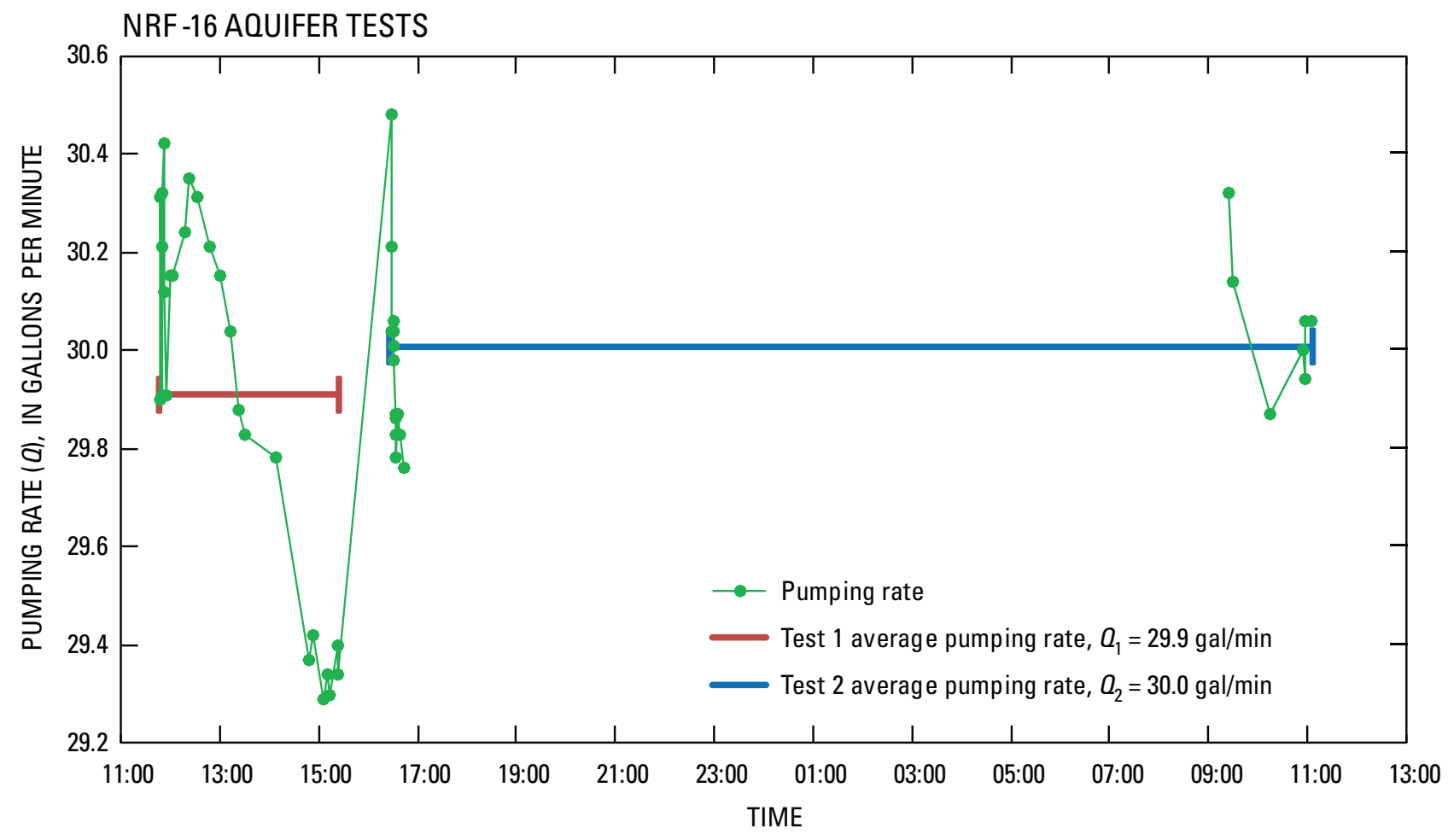

Figure 12. Pumping rates during the aquifer tests, Naval Reactors Facility, Idaho National Laboratory, Idaho, November 16-17, 2009.

\section{Analysis}

The single-well aquifer tests were analyzed using the Cooper-Jacob (1946) method. The Cooper-Jacob method is a simplification of the Theis (1935) solution and assumes that the pumping well fully penetrates a confined, homogeneous, and isotropic aquifer. Conditions for the NRF-16 single-well aquifer test depart greatly from the Theis (1935) model because the well partially penetrates an unconfined heterogeneous anisotropic aquifer. The Cooper-Jacob method was used, regardless of the differences between field conditions and theory, due to its simplicity. An analysis of single-well tests by Halford and others (2006) determined that estimating hydraulic properties from a single-well pumping test using anything other than the Cooper-Jacob method is unnecessary and that transmissivity is the only hydraulic property that could be estimated uniquely.

The Cooper-Jacob method estimates transmissivity by fitting a straight line to drawdowns on an arithmetic axis compared with time on a log-arithmetic axis. Transmissivity is determined from the slope of the straight line using the equation:

$$
T=\frac{2.3 Q}{4 \pi} \frac{1}{\Delta s},
$$

where

$T$ is transmissivity, $Q$ is the pumping rate, $\Delta s$ is the drawdown across one log cycle.

The drawdown in the well, $s$, at any given time, $t$, is determined by subtracting the pressure head at $t$ from the initial pressure head prior to pumping, $\Psi_{0}$. Drawdown as a function of time was calculated using the equation:

$$
s(t)=\psi_{0}-\psi(t) .
$$

Estimates of horizontal hydraulic conductivity were based on the aquifer thickness, $b$, rather than the screen length. Halford and others (2006) determined that using aquifer thickness as the divisor gave better estimates of transmissivity for unconfined aquifers with partial penetration in most cases. 
The horizontal hydraulic conductivity was calculated using the following equation:

$$
K=\frac{T}{b}
$$

where

$K$ is the horizontal hydraulic conductivity,

$T$ is transmissivity,

$b$ is the thickness of the saturated aquifer.

\section{Hydraulic Property Estimates}

The hydraulic properties of the geohydrologic column, from the water table to the bottom of borehole NRF-16, were defined with transmissivity and horizontal hydraulic conductivity. Estimates of these hydraulic properties were made for each aquifer test. The subscripts ${ }_{1}$ and 2 in equations 5 through 8 are used to designate the first and second aquifer tests, respectively. The Cooper-Jacob transmissivity was estimated for each test by an interpretive approach; all data were not honored and only relevant data were used to fit the semilog slopes. For example, a minimum time of 10 minutes for both aquifer tests was used to avoid early-time complications. The Cooper-Jacob method applied to the first aquifer test is shown in figure 13. The transmissivity and average conductivity for the first test were estimated at $4.5 \times 10^{3} \mathrm{ft}^{2} / \mathrm{d}$ and $9.2 \mathrm{ft} / \mathrm{d}$, respectively. Calculations of these two parameters are:

$$
\begin{aligned}
T_{1}= & \frac{2.3 Q_{1}}{4 \pi} \frac{1}{\Delta s_{1}}=\frac{2.3 \times 4.00 \mathrm{ft}^{3} / \mathrm{min}}{4 \pi \times 0.24 \mathrm{ft}}=3.1 \mathrm{ft}^{2} / \mathrm{min} \text { or } \\
& 4.5 \times 10^{3} \mathrm{ft}^{2} / \mathrm{d} . \\
K_{1}=\frac{T_{1}}{b}= & \frac{3.1 \mathrm{ft}^{2} / \mathrm{min}}{487 \mathrm{ft}}=6.3 \times 10^{-3} \mathrm{ft} / \mathrm{min} \text { or } 9.2 \mathrm{ft} / \mathrm{d} .
\end{aligned}
$$

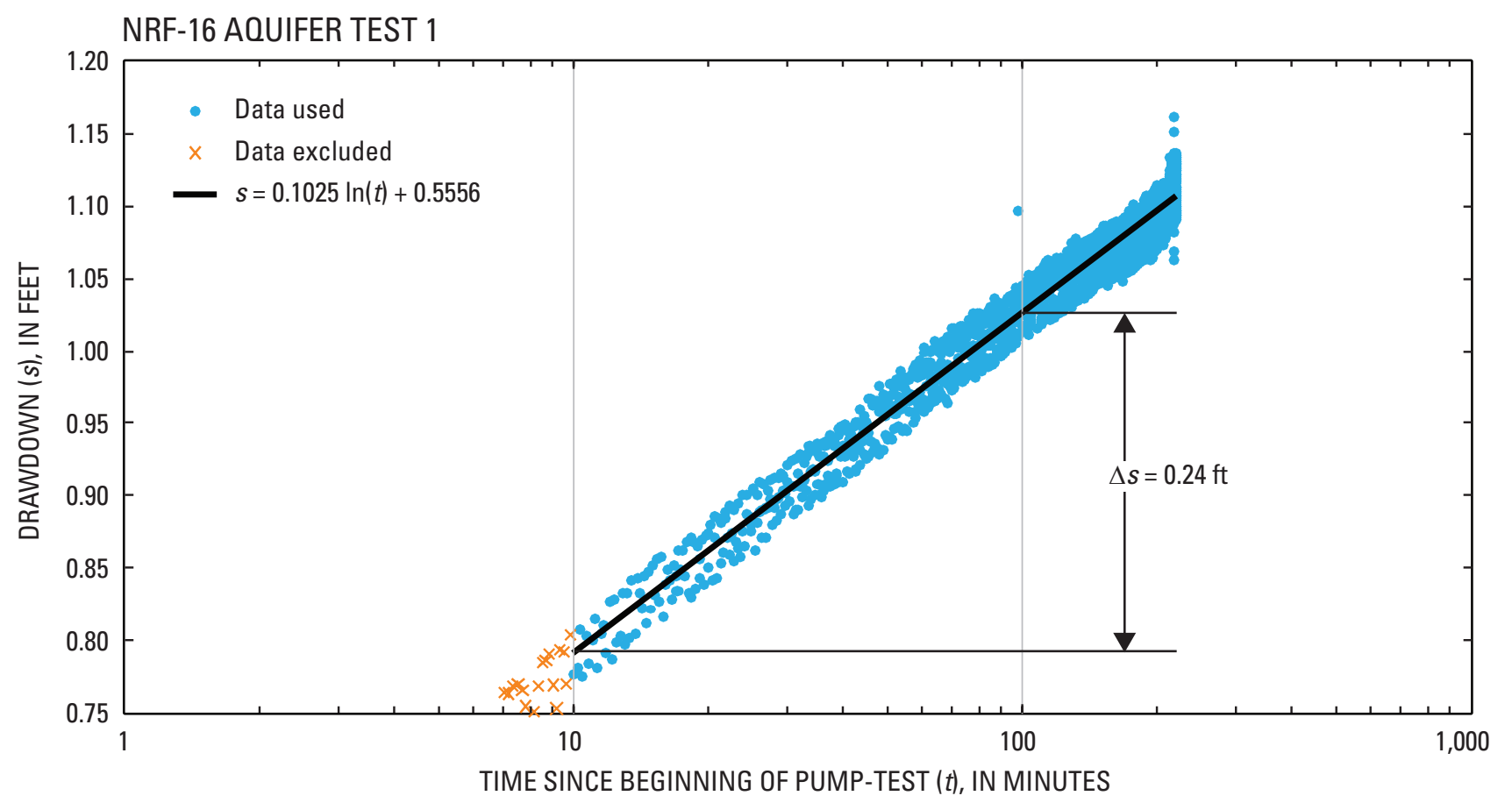

Figure 13. Analysis of drawdown time series for aquifer test 1 at well NRF-16, Naval Reactors Facility, Idaho National Laboratory, Idaho, November 16, 2009. 
In the second aquifer test, all data after 380 minutes were excluded from the analyses due to a pseudo steady-state achieved for later drawdowns (fig. 14). The transmissivity and average conductivity for the second test were estimated at $5.1 \times 10^{3} \mathrm{ft}^{2} / \mathrm{d}$ and $10.6 \mathrm{ft} / \mathrm{d}$, respectively. Calculations of these two parameters are:

$$
\begin{aligned}
T_{2}= & \frac{2.3 Q_{2}}{4 \pi} \frac{1}{\Delta s_{2}}=\frac{2.3 \times 4.01 \mathrm{ft}^{3} / \mathrm{min}}{4 \pi \times 0.21 \mathrm{ft}}=3.6 \mathrm{ft}^{2} / \mathrm{min} \text { or } \\
& 5.1 \times 10^{3} \mathrm{ft}^{2} / \mathrm{d} .
\end{aligned}
$$

$$
K_{2}=\frac{T_{2}}{b}=\frac{3.6 \mathrm{ft}^{2} / \mathrm{min}}{487 \mathrm{ft}}=7.4 \times 10^{-3} \mathrm{ft} / \mathrm{min} \text { or } 10.6 \mathrm{ft} / \mathrm{d} .
$$

The estimated hydraulic conductivities from the first and second tests are similar with a conductivity difference of $1.4 \mathrm{ft} / \mathrm{d}$. This difference possibly may be attributed to uncertainty in the Cooper-Jacob method and assumed saturated thickness and (or) a water-level at the start of the second aquifer test that was not fully recovered from the pumpage in the first test.

The average transmissivity and hydraulic conductivity for the two aquifer tests are $4.8 \times 10^{3} \mathrm{ft}^{2} / \mathrm{d}$ and $9.9 \mathrm{ft} / \mathrm{d}$, respectively. The estimated transmissivity was within the range of transmissivity values reported for past aquifer tests conducted at wells near well NRF-16 (fig. 2, table 4); although, the closest aquifer test was conducted more than $1 \mathrm{mi}$ from NRF-16. The estimated transmissivity values from these past aquifer tests (Ackerman, 1991) ranged from $4.4 \times 10^{2}$ to $5.1 \times 10^{5} \mathrm{ft}^{2} / \mathrm{d}$ with a 7 order of magnitude difference. The hydraulic conductivity of the eastern SRP aquifer at or near the INL ranges from about $1.0 \times 10^{-2}$ to $3.2 \times 10^{4} \mathrm{ft} / \mathrm{d}$ (Anderson and others, 1999).

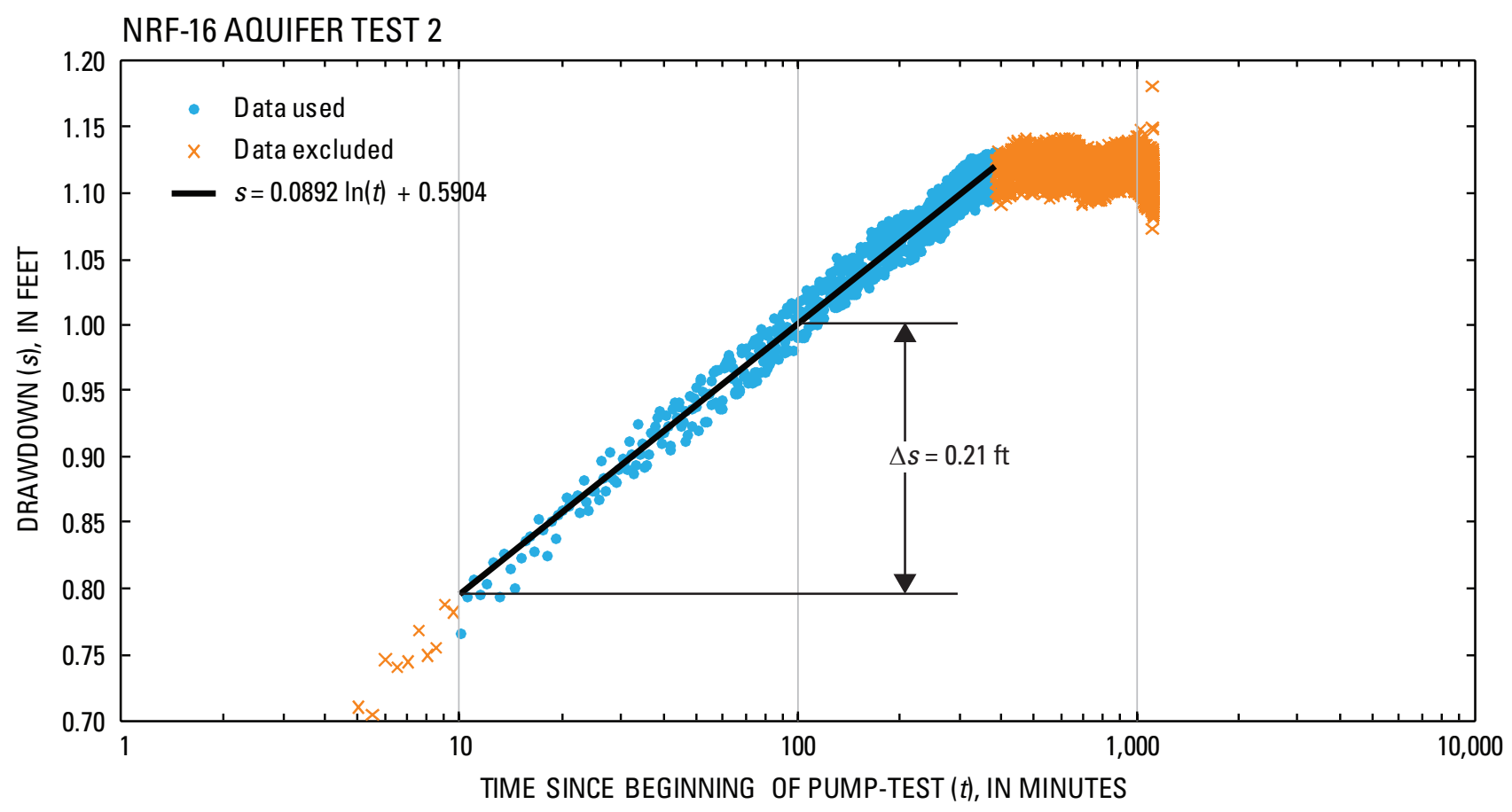

Figure 14. Analysis of drawdown time series for aquifer test 2 at well NRF-16, Naval Reactors Facility, Idaho National Laboratory, Idaho, November 16, 2009. 
Table 4. Comparison of transmissivity values estimated from aquifer tests conducted at wells near well NRF-16, near the Naval Reactors Facility, Idaho National Laboratory, Idaho.

[Locations of wells shown in figure 2. Local name is the local well identifier used in this study. Site identifier is the unique numerical identifier used to access well data (http://waterdata.usgs.gov/nwis). Relative uncertainty in orders of magnitude. Distance to NRF-16 is the straight line distance within the aerial dimension to well NRF-16. Abbreviations: NRF, Naval Reactors Facility; USGS, U.S. Geological Survey; $\mathrm{ft}^{2} / \mathrm{d}$, foot squared per day; mi, mile]

\begin{tabular}{llllccc}
\hline $\begin{array}{c}\text { Local } \\
\text { name }\end{array}$ & $\begin{array}{c}\text { Site } \\
\text { identifier }\end{array}$ & Longitude & Latitude & $\begin{array}{c}\text { Transmissivity } \\
\text { (ft' } \mathbf{d r}^{\text {d) }}\end{array}$ & $\begin{array}{c}\text { Relative } \\
\text { uncertainty }\end{array}$ & $\begin{array}{c}\text { Distance } \\
\text { to NRF-16 } \\
(\mathbf{m i})\end{array}$ \\
\hline NRF-16 & 434018112545101 & $112^{\circ} 54^{\prime} 518^{\prime \prime}$ & $43^{\circ} 40^{\prime} 18.5^{\prime \prime}$ & $4.8 \times 10^{3}$ & 0.1 & 0.00 \\
NRF-1 & 433859112545401 & $112^{\circ} 54^{\prime} 54^{\prime \prime}$ & $43^{\circ} 38^{\prime} 59^{\prime \prime}$ & $5.1 \times 10^{5}$ & .4 & 1.53 \\
NRF-3 & 433858112545501 & $112^{\circ} 54^{\prime} 55^{\prime \prime}$ & $43^{\circ} 38^{\prime} 58^{\prime \prime}$ & $2.9 \times 10^{4}$ & .4 & 1.55 \\
USGS 12 & 434126112550701 & $112^{\circ} 55^{\prime} 07.10^{\prime \prime}$ & $43^{\circ} 41^{\prime} 26.19^{\prime \prime}$ & $1.1 \times 10^{4}$ & .4 & 1.32 \\
USGS 17 & 433937112515401 & $112^{\circ} 51^{\prime} 54.27^{\prime \prime}$ & $43^{\circ} 39^{\prime} 36.42^{\prime \prime}$ & $4.4 \times 10^{2}$ & .1 & 2.59 \\
\hline
\end{tabular}

\section{Water Sample Collection}

\section{Sample Collection Methods}

Water sample collection by the USGS INL Project Office at the NRF generally followed guidelines established by the USGS and documented in the USGS National Field Manual (U.S. Geological Survey, variously dated) and Knobel and others (2008). The initial water samples collected prior to well completion were collected using a pre-cleaned stainless-steel thief sampling bottle that was lowered to about $408 \mathrm{ft} \mathrm{BLS}$ and filled with formation water. The stainless-steel bottle was then brought to the surface and emptied into a pre-cleaned container; the water was then processed to fill appropriate bottles for analyses. Field measurements also were taken from the pre-cleaned container. Field measurements of $\mathrm{pH}$, specific conductance, water temperature, dissolved oxygen, alkalinity, and turbidity are presented in table 5. Water samples were collected after completing and developing the monitoring well. The well was purged for more than 24 hours at about $30 \mathrm{gal} / \mathrm{min}$. Samples were collected after field measurements were stable from a 0.25 -in. stainless steel sample port installed off piping at the wellhead.

Field processing of samples differed depending on the constituents for which analyses were requested. The samples were analyzed by TestAmerica Laboratories and placed in containers and preserved in accordance with laboratory specifications (TestAmerica Laboratories, 2009a, tables 23-1-3). Some additional samples were collected and analyzed by the USGS National Water Quality Laboratory (NWQL) for comparison. The tritium sample collected for NRF-16 was analyzed at the Brigham Young University Laboratory of Isotope Geochemistry. Analytical methods used by the TestAmerica Laboratories for selected organic and inorganic constituents are described in TestAmerica Laboratories (2009a). Analytical methods used for radionuclide analyses are described in TestAmerica Laboratories (2009b). Analytical methods used by the USGS NWQL for selected organic and inorganic constituents are described by Goerlitz and Brown (1972), Wershaw and others (1987), Fishman and Friedman (1989), Faires (1993), Fishman (1993), and Rose and Schroeder (1995). Samples requiring filtration consisted of filtering the water through a disposable $0.45-\mu \mathrm{m}$ filter cartridge that had been pre-rinsed with at least $1 \mathrm{~L}$ of deionized water.

\section{Guidelines for Interpretation of Analytical Results}

Concentrations of radionuclides are reported with an estimated sample standard deviation, $s$, which is obtained by propagating sources of analytical uncertainty in measurements. McCurdy and others, (2008) provide details on interpreting radiological data used by the USGS. The guidelines for interpreting analytical results are based on an extension of a method proposed by Currie (1984) and are given in Davis (2008). In this report, radionuclide concentrations less than $3 s$ are considered to be less than a "reporting level." The reporting level should not be confused with the analytical method detection limit, which is based on laboratory procedures. 
Concentrations of inorganic and organic constituents analyzed by TestAmerica Laboratories are reported with reference to laboratory reporting limits (RL). The reporting limit is a threshold value below which results are qualified and is normally the lowest level at which measurements become quantitatively meaningful (TestAmerica Laboratories, 2009a). Some of the analytes were positively identified and the associated numerical value is greater than the method detection level but less than the reporting limit; these values are reported as estimated concentrations. Values reported as less than reporting limits in this report are considered not detected by the laboratory (TestAmerica Laboratories, 2009a).

Concentrations of inorganic and organic constituents analyzed at the NWQL are reported with reference to laboratory reporting levels (LRLs). Details about the approach used by the USGS regarding detection levels and reporting levels are available in Childress and others (1999).

\section{Water Chemistry Results}

Water samples were collected from USGS 17, which was used for drill water, from NRF-15 after initial coring, from NRF-16 after initial coring, and again from NRF-16 after developing the monitoring well. Results of analyses are presented in table 5. The initial results from a water sample collected from well NRF-15 on November 20, 2008, indicated that concentrations of chloride and sulfate were much larger than concentrations that normally would be expected of water from the eastern SRP aquifer near the NRF; therefore, additional samples were collected at two different depths on December 10, 2008. Results from that sampling also indicated larger than expected concentrations for chloride and sulfate (table 5), and a decision was made to drill a new monitoring well in a new location (Kelly Willie, Bechtel Bettis Corporation, written commun., April 6, 2009).

\section{Inorganic Chemistry Results}

Water samples were collected from well NRF-16 and analyzed for total and dissolved concentrations of calcium, potassium, magnesium, and sodium, and dissolved concentrations of bromide, chloride, fluoride, and sulfate (table 5). Total and dissolved concentrations of selected inorganic constituents including aluminum, antimony, arsenic, barium, beryllium, cadmium, chromium, copper, iron, lead, manganese, mercury, nickel, selenium, silver, thallium, and zinc also were determined. Total concentrations of nutrients including ammonia, nitrate plus nitrite, nitrite, orthophosphate, and total Kjedahl nitrogen were also determined. A comparison of the results between the thief sample collected in
August 2009 and the pumped sample collected in November 2009 indicate good stability of the chemistry in this well. For example dissolved concentrations of calcium were 40 and $43 \mathrm{mg} / \mathrm{L}$, respectively, magnesium, 16 and $15 \mathrm{mg} / \mathrm{L}$, respectively, potassium, estimated at $2.5 \mathrm{mg} / \mathrm{L}$ for both samples, sodium, 7.4 and $7.2 \mathrm{mg} / \mathrm{L}$, respectively, chloride, 14 for both samples, and sulfate, 22 and $23 \mathrm{mg} / \mathrm{L}$, respectively (table 5). Many of the total concentrations were higher in the thief sample than in the pumped sample, which probably was due to particulate matter in the water after drilling. Dissolved concentrations analyzed by the NWQL also were comparable to the dissolved concentrations analyzed by TestAmerica Laboratories (table 5).

The NRF criteria for a new upgradient well included a well that would produce chemical concentrations that are representative of water that flows under the NRF facility, but that has not been influenced by disposal practices at the NRF. The water table contour map at the NRF indicates that flow near the NRF moves mostly from the north to the south (fig. 4), so water from the NRF-16 area should flow under the NRF. Concentrations of chloride (14 mg/L), sulfate $(23 \mathrm{mg} / \mathrm{L})$, and nitrate $(0.6 \mathrm{mg} / \mathrm{L})$ in water from well NRF-16 (table 5) are well below estimated background levels $(20-40 \mathrm{mg} / \mathrm{L}$ for chloride, $30-40 \mathrm{mg} / \mathrm{L}$ for sulfate, and $0.9 \mathrm{mg} / \mathrm{L}$ for nitrate as nitrogen, [Robertson and others, 1974, figs. 24, 27, and 28]) for the eastern SRP aquifer upgradient of the NRF, which indicates that this well is not influenced by disposal practices at the NRF.

\section{Organic Chemistry Results}

Water samples from NRF-16 were collected and analyzed for total organic carbon, volatile organic compounds, semivolatile organic compounds, herbicides, pesticides, and polychlorinated biphenols (table 5). Water sample results indicate this well had only an estimated concentration of total organic carbon of $0.3 \mathrm{mg} / \mathrm{L}$ and an estimated concentration of toluene of $0.48 \mu \mathrm{g} / \mathrm{L}$. A sample analyzed by the NWQL had a comparable toluene concentration of $0.444 \mu \mathrm{g} / \mathrm{L}$ (table 5). No other organic compounds were detected.

\section{Radionuclide Results}

Water samples from NRF-16 were collected and analyzed for tritium at the Brigham Young University Laboratory of Isotope Geochemistry, and for Strontium-90, Nickel-63, and gross gamma at TestAmerica Laboratories. The tritium concentration was $18.3 \pm 0.355 \mathrm{pCi} / \mathrm{L}$ and all the other radionuclide concentrations were below the reporting level. 
Table 5. Concentrations of selected radiochemical and chemical constituents in water from wells USGS 17, NRF-15, and NRF-16, near the Naval Reactors Facility, Idaho National Laboratory, Idaho.

[Locations of wells shown in figure 2. Analytical results in micrograms per liter unless noted otherwise. Sample from well USGS 17 collected from pumped well. NRF-15 (11-20-08) sample collected from a thief sample from 394 feet below land surface. NRF-15 (12-10-08) samples collected from a thief sampler from 423 and 394 feet below land surface, respectively. NRF-16 (08-26-09) thief sample collected at about 400 feet below land surface. NRF-16 (11-17-09) samples were collected from a pumped well. NRF-16 well sampled on 11-17-09; samples analyzed at the National Water Quality Laboratory (NWQL). All other samples analyzed by Test America Laboratories except for NRF-16 (11-17-09) tritium sample analyzed at Brigham Young University Laboratory of Isotope Geochemistry. Pump was set at about 400 feet below land surface. Abbreviations: ${ }^{\circ} \mathrm{C}$, degrees Celsius; $\mu \mathrm{S} / \mathrm{cm}$, microsiemens per centimeter; $\mathrm{mg} / \mathrm{L}$, milligram per liter; NTU, nephlometric turbidity units; $\mathrm{CaCO}_{3}$, calcium carbonate; $\mathrm{pCi} / \mathrm{L}$, picocurie per liter; $\mathrm{N}$, nitrogen; $\mathrm{NC}$, not collected; $\mathrm{NS}$, not sampled; NA, not analyzed; PCBs, polychlorinated biphenols; USGS, U.S. Geological Survey; NRF, Naval Reactors Facility; E, estimated; <, less than]

\begin{tabular}{|c|c|c|c|c|c|c|c|}
\hline Constituent or measurement & $\begin{array}{c}\text { USGS } 17 \\
(11-03-08)\end{array}$ & $\begin{array}{c}\text { NRF-15 } \\
(11-20-08)\end{array}$ & $\begin{array}{c}\text { NRF-15 } \\
(12-10-08)\end{array}$ & $\begin{array}{c}\text { NRF-15 } \\
(12-10-08)\end{array}$ & $\begin{array}{c}\text { NRF-16 } \\
(08-26-09)\end{array}$ & $\begin{array}{c}\text { NRF-16 } \\
(11-17-09)\end{array}$ & $\begin{array}{l}\text { NRF-16 } \\
\text { (NWQL) }\end{array}$ \\
\hline Time & 1212 & 1416 & 1212 & 1345 & 1145 & 1025 & 1025 \\
\hline Air Temperature $\left({ }^{\circ} \mathrm{C}\right)$ & 10.2 & 12.3 & 1.6 & 2 & 25.5 & 1.6 & 1.6 \\
\hline pH (field) & 7.96 & 7.44 & 7.62 & 7.71 & 7.84 & 7.52 & 7.52 \\
\hline $\mathrm{pH}(\mathrm{lab})$ & NA & NA & NA & NA & NA & NA & 7.67 \\
\hline Dissolved oxygen $(\mathrm{mg} / \mathrm{L})$ & 9.25 & 7.63 & 10.14 & 9.76 & 8.24 & 8.87 & 8.87 \\
\hline Turbidity (NTU) & 84.2 & $\mathrm{NC}$ & $\mathrm{NC}$ & $\mathrm{NC}$ & $\mathrm{NC}$ & .62 & .62 \\
\hline Alkalinity $\left(\mathrm{mg} / \mathrm{L}\right.$ as $\left.\mathrm{CaCO}_{3}\right)$, Field & 132 & 102 & 111 & 106 & 136 & 145 & 145 \\
\hline Alkalinity $\left(\mathrm{mg} / \mathrm{L}\right.$ as $\left.\mathrm{CaCO}_{3}\right)$, Lab & NS & NA & NA & NA & NA & NA & 154 \\
\hline Total dissolved solids $(\mathrm{mg} / \mathrm{L})$ & 161 & 310 & 419 & 412 & 194 & 200 & $231 \mathrm{E}$ \\
\hline Potassium, total (mg/L) & E2.8 & 4.2 & 7.2 & 6 & 5.7 & E2.6 & NS \\
\hline Potassium, filtered (mg/L) & NS & $\mathrm{E} 2.8$ & 3.8 & 4.3 & E2.5 & $\mathrm{E} 2.5$ & 2.5 \\
\hline Sodium, total $(\mathrm{mg} / \mathrm{L})$ & 7 & 23 & 23 & 22 & 8.5 & 7.3 & NS \\
\hline Sodium, filtered (mg/L) & NS & 12 & 19 & 19 & 7.4 & 7.2 & 7.3 \\
\hline Bromide (mg/L) & NS & NS & NS & NS & NS & $<0.2$ & NS \\
\hline Chloride (mg/L) & 6.6 & 64 & 96 & 96 & 14 & 14 & 13.7 \\
\hline Fluoride (mg/L) & NS & NS & NS & NS & NS & E0.2 & .21 \\
\hline Sulfate $(\mathrm{mg} / \mathrm{L})$ & 20 & 84 & 130 & 120 & 22 & 23 & 23.3 \\
\hline Ammonia as $\mathrm{N}(\mathrm{mg} / \mathrm{L})$ & NS & NS & NS & NS & NS & E.054 & $<.02$ \\
\hline Nitrate plus nitrite as $\mathrm{N}(\mathrm{mg} / \mathrm{L})$ & .34 & NS & .88 & .89 & 0.43 & .6 & .64 \\
\hline Nitrite as $N(\mathrm{mg} / \mathrm{L})$ & $<.50$ & $<0.5$ & $<.5$ & $<.5$ & $<0.5$ & $<.5$ & $<.002$ \\
\hline Arsenic, filtered & NS & E.26 & E3.7 & E.29 & $<5.0$ & E1.8 & 1.94 \\
\hline Barium, total & 64 & 200 & 390 & 260 & 260 & 78 & NS \\
\hline Barium, filtered & NS & 47 & 92 & 99 & 60 & 75 & 74 \\
\hline Beryllium, total & $<5.0$ & E.69 & E1.5 & E.97 & E1.2 & $<5.0$ & NS \\
\hline Beryllium, filtered & NS & $<5.0$ & $<5.0$ & $<5.0$ & $<5.0$ & $<5.0$ & $<0.2$ \\
\hline Boron, filtered & NS & NS & NS & NS & NS & NS & 12.6 \\
\hline Cadmium, total & $<5.0$ & $<5.0$ & $<5.0$ & E.57 & E.6 & $<5.0$ & NS \\
\hline Cadmium, filtered & NS & E.70 & $<5.0$ & $<5.0$ & $<5.0$ & $<5.0$ & $.018 \mathrm{E}$ \\
\hline Chromium, total & 5.9 & 80 & 34 & 58 & 34 & 7.9 & NS \\
\hline Chromium, filtered & NS & $<2.0$ & E.61 & $<2.0$ & $<2.0$ & 7.8 & 7.4 \\
\hline Cobalt, filtered & NS & NA & NA & NA & NA & NA & .1 \\
\hline
\end{tabular}


Table 5. Concentrations of selected radiochemical and chemical constituents in water from wells USGS 17, NRF-15, and NRF-16, near the Naval Reactors Facility, Idaho National Laboratory, Idaho.-Continued

[Locations of wells shown in figure 2. Analytical results in micrograms per liter unless noted otherwise. Sample from well USGS 17 collected from pumped well. NRF-15 (11-20-08) sample collected from a thief sample from 394 feet below land surface. NRF-15 (12-10-08) samples collected from a thief sampler from 423 and 394 feet below land surface, respectively. NRF-16 (08-26-09) thief sample collected at about 400 feet below land surface. NRF-16 (11-17-09) samples were collected from a pumped well. NRF-16 well sampled on 11-17-09; samples analyzed at the National Water Quality Laboratory (NWQL). All other samples analyzed by Test America Laboratories except for NRF-16 (11-17-09) tritium sample analyzed at Brigham Young University Laboratory of Isotope Geochemistry. Pump was set at about 400 feet below land surface. Abbreviations: ${ }^{\circ} \mathrm{C}$, degrees Celsius; $\mu \mathrm{S} / \mathrm{cm}$, microsiemens per centimeter; $\mathrm{mg} / \mathrm{L}$, milligram per liter; NTU, nephlometric turbidity units; $\mathrm{CaCO}_{3}$, calcium carbonate; $\mathrm{pCi} / \mathrm{L}$, picocurie per liter; $\mathrm{N}$, nitrogen; $\mathrm{NC}$, not collected; $\mathrm{NS}$, not sampled; NA, not analyzed; PCBs, polychlorinated biphenols; USGS, U.S. Geological Survey; NRF, Naval Reactors Facility; E, estimated; <, less than]

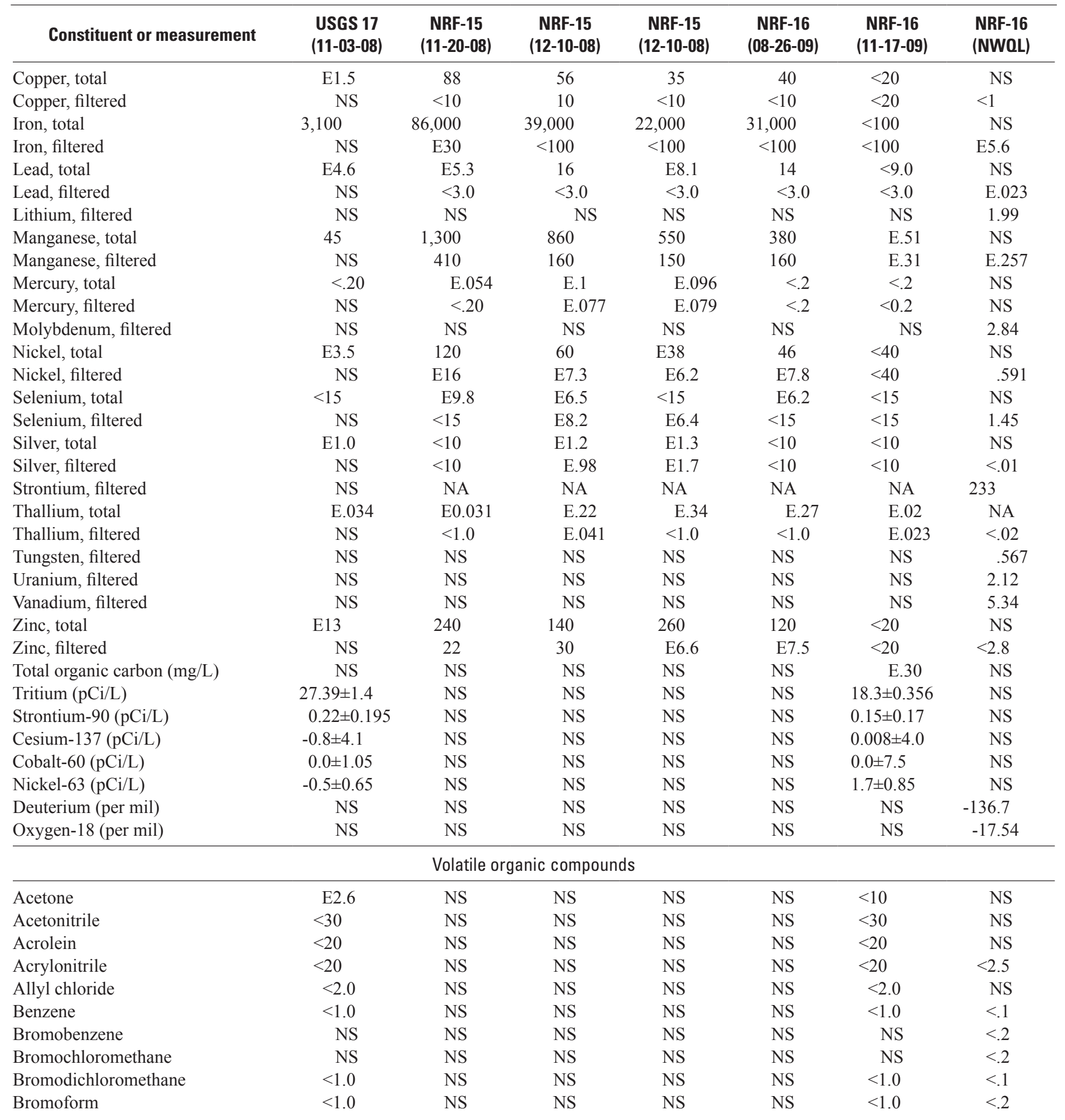


Table 5. Concentrations of selected radiochemical and chemical constituents in water from wells USGS 17, NRF-15, and NRF-16, near the Naval Reactors Facility, Idaho National Laboratory, Idaho.-Continued

[Locations of wells shown in figure 2. Analytical results in micrograms per liter unless noted otherwise. Sample from well USGS 17 collected from pumped well. NRF-15 (11-20-08) sample collected from a thief sample from 394 feet below land surface. NRF-15 (12-10-08) samples collected from a thief sampler from 423 and 394 feet below land surface, respectively. NRF-16 (08-26-09) thief sample collected at about 400 feet below land surface. NRF-16 (11-17-09) samples were collected from a pumped well. NRF-16 well sampled on 11-17-09; samples analyzed at the National Water Quality Laboratory (NWQL). All other samples analyzed by Test America Laboratories except for NRF-16 (11-17-09) tritium sample analyzed at Brigham Young University Laboratory of Isotope Geochemistry. Pump was set at about 400 feet below land surface. Abbreviations: ${ }^{\circ} \mathrm{C}$, degrees Celsius; $\mu \mathrm{S} / \mathrm{cm}$, microsiemens per centimeter; $\mathrm{mg} / \mathrm{L}$, milligram per liter; NTU, nephlometric turbidity units; $\mathrm{CaCO}_{3}$, calcium carbonate; $\mathrm{pCi} / \mathrm{L}$, picocurie per liter; $\mathrm{N}$, nitrogen; $\mathrm{NC}$, not collected; $\mathrm{NS}$, not sampled; NA, not analyzed; PCBs, polychlorinated biphenols; USGS, U.S. Geological Survey; NRF, Naval Reactors Facility; E, estimated; <, less than]

\begin{tabular}{|c|c|c|c|c|c|c|c|}
\hline Constituent or measurement & $\begin{array}{l}\text { USGS } 17 \\
(11-03-08)\end{array}$ & $\begin{array}{c}\text { NRF-15 } \\
(11-20-08)\end{array}$ & $\begin{array}{c}\text { NRF-15 } \\
(12-10-08)\end{array}$ & $\begin{array}{c}\text { NRF-15 } \\
(12-10-08)\end{array}$ & $\begin{array}{c}\text { NRF-16 } \\
(08-26-09)\end{array}$ & $\begin{array}{c}\text { NRF-16 } \\
(11-17-09)\end{array}$ & $\begin{array}{l}\text { NRF-16 } \\
\text { (NWOL) }\end{array}$ \\
\hline \multicolumn{8}{|c|}{ Volatile organic compounds-Continued } \\
\hline Carbon disulfide & $<2.0$ & NS & NS & NS & NS & $<2.0$ & NS \\
\hline Carbon tetrachloride & $<1.0$ & NS & NS & NS & NS & $<1.0$ & $<.2$ \\
\hline Chloroethane & $<2.0$ & NS & NS & NS & NS & $<2.0$ & $<.2$ \\
\hline Chloroform & $<1.0$ & NS & NS & NS & NS & $<1.0$ & $<.1$ \\
\hline Chloromethane & $<2.0$ & NS & NS & NS & NS & $<2.0$ & $<.2$ \\
\hline Chloroprene & $<1.0$ & NS & NS & NS & NS & $<1.0$ & NS \\
\hline cis-1,2-dichloroethene & NS & NS & NS & NS & NS & NS & $<.1$ \\
\hline cis-1,3-dichloropropene & $<1.0$ & NS & NS & NS & NS & $<1.0$ & $<.2$ \\
\hline Dichlorodifluoromethane & $<2.0$ & NS & NS & NS & NS & $<2.0$ & $<.2$ \\
\hline Ethyl methacrylate & $<3.0$ & NS & NS & NS & NS & $<3.0$ & NS \\
\hline Ethylbenzene & $<1.0$ & NS & NS & NS & NS & $<1.0$ & $<.1$ \\
\hline Iodomethane & $<1.0$ & NS & NS & NS & NS & $<1.0$ & NS \\
\hline Isobutyl alcohol & $<110$ & NS & NS & NS & NS & $<110$ & NS \\
\hline Isopropylbenzene & NS & NS & NS & NS & NS & NS & $<.2$ \\
\hline Methacrylonitrile & $<10$ & NS & NS & NS & NS & $<10$ & NS \\
\hline Methyl methacrylate & $<4$ & NS & NS & NS & NS & $<4$ & NS \\
\hline Methyl tertiary butyl ether (MTBE) & NS & NS & NS & NS & NS & NS & $<.2$ \\
\hline$n$-butylbenzene & NS & NS & NS & NS & NS & NS & $<.2$ \\
\hline$n$-propylbenzene & NS & NS & NS & NS & NS & NS & $<.2$ \\
\hline trans-1,4-dichloro-2-butene & $<3.0$ & NS & NS & NS & NS & $<3.0$ & NS \\
\hline Trichloroethene & $<1.0$ & NS & NS & NS & NS & $<1.0$ & $<.1$ \\
\hline Trichlorofluoromethane & $<2.0$ & NS & NS & NS & NS & $<2.0$ & $<.2$ \\
\hline Vinyl acetate & $<3.0$ & NS & NS & NS & NS & $<3.0$ & NS \\
\hline Vinyl chloride & $<1.0$ & NS & NS & NS & NS & $<1.0$ & $<.2$ \\
\hline Xylene & $<2.0$ & NS & NS & NS & NS & $<2.0$ & $<.2$ \\
\hline 1,1,1,2-tetrachloroethane & $<1.0$ & NS & NS & NS & NS & $<1.0$ & $<.2$ \\
\hline 1,1,1-trichloroethane & $<1.0$ & NS & NS & NS & NS & $<1.0$ & $<.1$ \\
\hline 1,1,2,2-tetrachloroethane & $<1.0$ & NS & NS & NS & NS & $<1.0$ & $<.2$ \\
\hline 1,1,2-trichloroethane & $<1.0$ & NS & NS & NS & NS & $<1.0$ & $<.2$ \\
\hline 1,1-dichloroethane & $<1.0$ & NS & NS & NS & NS & $<1.0$ & $<.1$ \\
\hline
\end{tabular}


Table 5. Concentrations of selected radiochemical and chemical constituents in water from wells USGS 17, NRF-15, and NRF-16, near the Naval Reactors Facility, Idaho National Laboratory, Idaho.-Continued

[Locations of wells shown in figure 2. Analytical results in micrograms per liter unless noted otherwise. Sample from well USGS 17 collected from pumped well. NRF-15 (11-20-08) sample collected from a thief sample from 394 feet below land surface. NRF-15 (12-10-08) samples collected from a thief sampler from 423 and 394 feet below land surface, respectively. NRF-16 (08-26-09) thief sample collected at about 400 feet below land surface. NRF-16 (11-17-09) samples were collected from a pumped well. NRF-16 well sampled on 11-17-09; samples analyzed at the National Water Quality Laboratory (NWQL). All other samples analyzed by Test America Laboratories except for NRF-16 (11-17-09) tritium sample analyzed at Brigham Young University Laboratory of Isotope Geochemistry. Pump was set at about 400 feet below land surface. Abbreviations: ${ }^{\circ} \mathrm{C}$, degrees Celsius; $\mu \mathrm{S} / \mathrm{cm}$, microsiemens per centimeter; $\mathrm{mg} / \mathrm{L}$, milligram per liter; NTU, nephlometric turbidity units; $\mathrm{CaCO}_{3}$, calcium carbonate; $\mathrm{pCi} / \mathrm{L}$, picocurie per liter; $\mathrm{N}$, nitrogen; $\mathrm{NC}$, not collected; $\mathrm{NS}$, not sampled; NA, not analyzed; PCBs, polychlorinated biphenols; USGS, U.S. Geological Survey; NRF, Naval Reactors Facility; E, estimated; <, less than]

\begin{tabular}{|c|c|c|c|c|c|c|c|}
\hline Constituent or measurement & $\begin{array}{l}\text { USGS } 17 \\
(11-03-08)\end{array}$ & $\begin{array}{l}\text { NRF-15 } \\
(11-20-08)\end{array}$ & $\begin{array}{c}\text { NRF-15 } \\
(12-10-08)\end{array}$ & $\begin{array}{l}\text { NRF-15 } \\
(12-10-08)\end{array}$ & $\begin{array}{l}\text { NRF-16 } \\
(08-26-09)\end{array}$ & $\begin{array}{c}\text { NRF-16 } \\
(11-17-09)\end{array}$ & $\begin{array}{l}\text { NRF-16 } \\
\text { (NWQL) }\end{array}$ \\
\hline \multicolumn{8}{|c|}{ Volatile organic compounds-Continued } \\
\hline 1,1-dichloropropene & NS & NS & NS & NS & NS & NS & $<.2$ \\
\hline 1,2,3-trichloropropane & $<2.5$ & NS & NS & NS & NS & $<2.5$ & $<.2$ \\
\hline $\begin{array}{l}\text { 1,2-Dibromo-3-chloropropane } \\
\text { (DBCP) }\end{array}$ & $<5.0$ & NS & NS & NS & NS & $<5.0$ & $<.5$ \\
\hline 1,2-dibromoethane & $<1.0$ & NS & NS & NS & NS & $<1.0$ & $<.2$ \\
\hline 1,2-dichloroethane & $<1.0$ & NS & NS & NS & NS & $<1.0$ & $<.2$ \\
\hline 1,2-dichloropropane & $<1.0$ & NS & NS & NS & NS & $<1.0$ & $<.1$ \\
\hline 1,3-dichloropropane & NS & NS & NS & NS & NS & NS & $<.2$ \\
\hline 2-butanone (MEK) & $<6.0$ & NS & NS & NS & NS & $<6.0$ & NS \\
\hline 2-chlorotoluene & NS & NS & NS & NS & NS & NS & $<.2$ \\
\hline 2-hexanone & $<5.0$ & NS & NS & NS & NS & $<5.0$ & NS \\
\hline 2,2-dichloropropane & NS & NS & NS & NS & NS & NS & $<.2$ \\
\hline 4-chlorotoluene & NS & NS & NS & NS & NS & NS & $<.2$ \\
\hline 4-isopropyltoluene & NS & NS & NS & NS & NS & NS & $<.2$ \\
\hline 4-methyl-2-pentanone & $<5.0$ & NS & NS & NS & NS & $<5.0$ & NS \\
\hline \multicolumn{8}{|c|}{ Semi-volatile organic compounds } \\
\hline a,a-dimethylphenethylamine & $<50$ & NS & NS & NS & NS & $<50$ & NS \\
\hline Acenaphthene & $<4.0$ & NS & NS & NS & NS & $<4.0$ & NS \\
\hline Benzo-[ghi]-perylene & $<4.0$ & NS & NS & NS & NS & $<4.0$ & NS \\
\hline Benzo-[k]-fluoranthene & $<4.0$ & NS & NS & NS & NS & $<4.0$ & NS \\
\hline Benzyl alcohol & $<10$ & NS & NS & NS & NS & $<10$ & NS \\
\hline Bis (2-chloroethyl) ether & $<10$ & NS & NS & NS & NS & $<10$ & NS \\
\hline Bis (2-chloroethoxy) methane & $<10$ & NS & NS & NS & NS & $<10$ & NS \\
\hline Bis (2-chloroisopropyl) ether & $<10$ & NS & NS & NS & NS & $<10$ & NS \\
\hline Bis (2-ethylhexyl) phthalate & E2.3 & NS & NS & NS & NS & $<10$ & NS \\
\hline Benxyl $n$-butylphthalate & $<4.0$ & NS & NS & NS & NS & $<4.0$ & NS \\
\hline Chlorobenzilate & $<10$ & NS & NS & NS & NS & $<10$ & NS \\
\hline Chrysene & $<4.0$ & NS & NS & NS & NS & $<4.0$ & NS \\
\hline Diallate & $<20$ & NS & NS & NS & NS & $<20$ & NS \\
\hline
\end{tabular}


Table 5. Concentrations of selected radiochemical and chemical constituents in water from wells USGS 17, NRF-15, and NRF-16, near the Naval Reactors Facility, Idaho National Laboratory, Idaho.-Continued

[Locations of wells shown in figure 2. Analytical results in micrograms per liter unless noted otherwise. Sample from well USGS 17 collected from pumped well. NRF-15 (11-20-08) sample collected from a thief sample from 394 feet below land surface. NRF-15 (12-10-08) samples collected from a thief sampler from 423 and 394 feet below land surface, respectively. NRF-16 (08-26-09) thief sample collected at about 400 feet below land surface. NRF-16 (11-17-09) samples were collected from a pumped well. NRF-16 well sampled on 11-17-09; samples analyzed at the National Water Quality Laboratory (NWQL). All other samples analyzed by Test America Laboratories except for NRF-16 (11-17-09) tritium sample analyzed at Brigham Young University Laboratory of Isotope Geochemistry. Pump was set at about 400 feet below land surface. Abbreviations: ${ }^{\circ} \mathrm{C}$, degrees Celsius; $\mu \mathrm{S} / \mathrm{cm}$, microsiemens per centimeter; $\mathrm{mg} / \mathrm{L}$, milligram per liter; NTU, nephlometric turbidity units; $\mathrm{CaCO}_{3}$, calcium carbonate; $\mathrm{pCi} / \mathrm{L}$, picocurie per liter; $\mathrm{N}$, nitrogen; $\mathrm{NC}$, not collected; $\mathrm{NS}$, not sampled; NA, not analyzed; PCBs, polychlorinated biphenols; USGS, U.S. Geological Survey; NRF, Naval Reactors Facility; E, estimated; <, less than]

\begin{tabular}{|c|c|c|c|c|c|c|c|}
\hline Constituent or measurement & $\begin{array}{c}\text { USGS } 17 \\
(11-03-08)\end{array}$ & $\begin{array}{c}\text { NRF-15 } \\
(11-20-08)\end{array}$ & $\begin{array}{c}\text { NRF-15 } \\
(12-10-08)\end{array}$ & $\begin{array}{c}\text { NRF-15 } \\
(12-10-08)\end{array}$ & $\begin{array}{c}\text { NRF-16 } \\
(08-26-09)\end{array}$ & $\begin{array}{c}\text { NRF-16 } \\
(11-17-09)\end{array}$ & $\begin{array}{l}\text { NRF-16 } \\
\text { (NWOL) }\end{array}$ \\
\hline \multicolumn{8}{|c|}{ Semi-volatile organic compounds-Continued } \\
\hline dibenzofuran & $<4.0$ & NS & NS & NS & NS & $<4.0$ & NS \\
\hline Diethyl phthalate & $<4.0$ & NS & NS & NS & NS & $<4.0$ & NS \\
\hline Di-n-butylphthalate & $<4.0$ & NS & NS & NS & NS & $<4.0$ & NS \\
\hline Di-n-octylphthalate & $<4.0$ & NS & NS & NS & NS & $<4.0$ & NS \\
\hline Diphenylamine & $<10$ & NS & NS & NS & NS & $<10$ & NS \\
\hline Disulfoton & $<50$ & NS & NS & NS & NS & $<50$ & NS \\
\hline Ethyl methanesulfonate & $<10$ & NS & NS & NS & NS & $<10$ & NS \\
\hline Famphur & NA & NS & NS & NS & NS & $<100$ & NS \\
\hline Hexachlorobutadiene & $<10$ & NS & NS & NS & NS & $<10$ & $<0.2$ \\
\hline Hexachlorocyclopentadiene & $<50$ & NS & NS & NS & NS & $<50$ & NS \\
\hline Hexachloroethane & $<10$ & NS & NS & NS & NS & $<10$ & NS \\
\hline Hexachlorophene & NA & NS & NS & NS & NS & $<1,000$ & NS \\
\hline Hexachloropropene & $<100$ & NS & NS & NS & NS & $<100$ & NS \\
\hline Indeno-[1,2,3-cd]-pyrene & $<4.0$ & NS & NS & NS & NS & $<4.0$ & NS \\
\hline Isodrin & NA & NS & NS & NS & NS & $<10$ & NS \\
\hline Isophorone & $<10$ & NS & NS & NS & NS & $<10$ & NS \\
\hline Isosafrole & $<20$ & NS & NS & NS & NS & $<20$ & NS \\
\hline Methapyrilene & $<50$ & NS & NS & NS & NS & $<50$ & NS \\
\hline Methyl methanesulfonate & $<10$ & NS & NS & NS & NS & $<10$ & NS \\
\hline N-nitrosodiphenylamine & $<10$ & NS & NS & NS & NS & $<10$ & NS \\
\hline N-nitrosomethylethylamine & $<10$ & NS & NS & NS & NS & $<10$ & NS \\
\hline N-nitrosomorpholine & $<10$ & NS & NS & NS & NS & $<10$ & NS \\
\hline N-nitrosopiperidine & $<10$ & NS & NS & NS & NS & $<10$ & NS \\
\hline N-nitrosopyrrolidine & $<10$ & NS & NS & NS & NS & $<10$ & NS \\
\hline OOO-triethyl phosphorothioate & $<50$ & NS & NS & NS & NS & $<50$ & NS \\
\hline o-toluidine & $<10$ & NS & NS & NS & NS & $<10$ & NS \\
\hline Parathion & NA & NS & NS & NS & NS & $<50$ & NS \\
\hline Pentachlorobenzene & $<10$ & NS & NS & NS & NS & $<10$ & NS \\
\hline Pentachloroethane & $<50$ & NS & NS & NS & NS & $<50$ & NS \\
\hline Pentachloronitrobenzene & $<50$ & NS & NS & NS & NS & $<50$ & NS \\
\hline
\end{tabular}


Table 5. Concentrations of selected radiochemical and chemical constituents in water from wells USGS 17, NRF-15, and NRF-16, near the Naval Reactors Facility, Idaho National Laboratory, Idaho.-Continued

[Locations of wells shown in figure 2. Analytical results in micrograms per liter unless noted otherwise. Sample from well USGS 17 collected from pumped well. NRF-15 (11-20-08) sample collected from a thief sample from 394 feet below land surface. NRF-15 (12-10-08) samples collected from a thief sampler from 423 and 394 feet below land surface, respectively. NRF-16 (08-26-09) thief sample collected at about 400 feet below land surface. NRF-16 (11-17-09) samples were collected from a pumped well. NRF-16 well sampled on 11-17-09; samples analyzed at the National Water Quality Laboratory (NWQL). All other samples analyzed by Test America Laboratories except for NRF-16 (11-17-09) tritium sample analyzed at Brigham Young University Laboratory of Isotope Geochemistry. Pump was set at about 400 feet below land surface. Abbreviations: ${ }^{\circ} \mathrm{C}$, degrees Celsius; $\mu \mathrm{S} / \mathrm{cm}$, microsiemens per centimeter; $\mathrm{mg} / \mathrm{L}$, milligram per liter; NTU, nephlometric turbidity units; $\mathrm{CaCO}_{3}$, calcium carbonate; $\mathrm{pCi} / \mathrm{L}$, picocurie per liter; $\mathrm{N}$, nitrogen; $\mathrm{NC}$, not collected; $\mathrm{NS}$, not sampled; NA, not analyzed; PCBs, polychlorinated biphenols; USGS, U.S. Geological Survey; NRF, Naval Reactors Facility; E, estimated; <, less than]

\begin{tabular}{|c|c|c|c|c|c|c|c|}
\hline Constituent or measurement & $\begin{array}{c}\text { USGS } 17 \\
(11-03-08)\end{array}$ & $\begin{array}{c}\text { NRF-15 } \\
(11-20-08)\end{array}$ & $\begin{array}{c}\text { NRF-15 } \\
(12-10-08)\end{array}$ & $\begin{array}{c}\text { NRF-15 } \\
(12-10-08)\end{array}$ & $\begin{array}{c}\text { NRF-16 } \\
(08-26-09)\end{array}$ & $\begin{array}{c}\text { NRF-16 } \\
(11-17-09)\end{array}$ & $\begin{array}{c}\text { NRF-16 } \\
\text { (NWQL) }\end{array}$ \\
\hline \multicolumn{8}{|c|}{ Semi-volatile organic compounds-Continued } \\
\hline Phenacetin & $<20$ & NS & NS & NS & NS & $<20$ & NS \\
\hline Phenanthrene & $<4.0$ & NS & NS & NS & NS & $<4.0$ & NS \\
\hline Pronamide & NA & NS & NS & NS & NS & $<20$ & NS \\
\hline Pyrene & $<10$ & NS & NS & NS & NS & $<10$ & NS \\
\hline Pyridine & $<20$ & NS & NS & NS & NS & $<20$ & NS \\
\hline Safrole & $<20$ & NS & NS & NS & NS & $<20$ & NS \\
\hline Sulfotepp & NA & NS & NS & NS & NS & $<50$ & NS \\
\hline Thionazin & NA & NS & NS & NS & NS & $<50$ & NS \\
\hline 1,3,5-trinitrobenzene & $<50$ & NS & NS & NS & NS & $<50$ & NS \\
\hline 1,3-dichlorobenzene & $<4.0$ & NS & NS & NS & NS & $<4.0$ & $<.1$ \\
\hline 1,3-dinitrobenzene & $<10$ & NS & NS & NS & NS & $<10$ & NS \\
\hline 1,4-dichlorobenzene & $<4.0$ & NS & NS & NS & NS & $<4.0$ & NS \\
\hline 1,4-naphthoquinone & $<50$ & NS & NS & NS & NS & $<50$ & NS \\
\hline 1-naphthylamine & $<10$ & NS & NS & NS & NS & $<10$ & NS \\
\hline 2,3,4,6-tetrachlorophenol & $<50$ & NS & NS & NS & NS & $<50$ & NS \\
\hline 2,4,5-trichlorophenol & $<10$ & NS & NS & NS & NS & $<10$ & NS \\
\hline 2,4,6-trichlorophenol & $<10$ & NS & NS & NS & NS & $<10$ & NS \\
\hline 2,4-dichlorophenol & $<10$ & NS & NS & NS & NS & $<10$ & NS \\
\hline 2,4-dimethylphenol & $<10$ & NS & NS & NS & NS & $<10$ & NS \\
\hline 2-methylphenol & $<10$ & NS & NS & NS & NS & $<10$ & NS \\
\hline 2-naphthylamine & $<10$ & NS & NS & NS & NS & $<10$ & NS \\
\hline 2-nitroaniline & $<10$ & NS & NS & NS & NS & $<10$ & NS \\
\hline 2-nitrophenol & $<10$ & NS & NS & NS & NS & $<10$ & NS \\
\hline 2-picoline & $<20$ & NS & NS & NS & NS & $<20$ & NS \\
\hline 3,3'-dichlorobenzidine & $<50$ & NS & NS & NS & NS & $<50$ & NS \\
\hline 3,3'-dimethylbenzidine & $<20$ & NS & NS & NS & NS & $<20$ & NS \\
\hline 3-methylcholanthrene & $<20$ & NS & NS & NS & NS & $<20$ & NS \\
\hline 3-methylphenol & $<10$ & NS & NS & NS & NS & $<10$ & NS \\
\hline 3-nitroaniline & $<10$ & NS & NS & NS & NS & $<10$ & NS \\
\hline 2-methyl-4,6-dinitrophenol & $<50$ & NS & NS & NS & NS & $<50$ & NS \\
\hline
\end{tabular}


Table 5. Concentrations of selected radiochemical and chemical constituents in water from wells USGS 17, NRF-15, and NRF-16, near the Naval Reactors Facility, Idaho National Laboratory, Idaho.-Continued

[Locations of wells shown in figure 2. Analytical results in micrograms per liter unless noted otherwise. Sample from well USGS 17 collected from pumped well. NRF-15 (11-20-08) sample collected from a thief sample from 394 feet below land surface. NRF-15 (12-10-08) samples collected from a thief sampler from 423 and 394 feet below land surface, respectively. NRF-16 (08-26-09) thief sample collected at about 400 feet below land surface. NRF-16 (11-17-09) samples were collected from a pumped well. NRF-16 well sampled on 11-17-09; samples analyzed at the National Water Quality Laboratory (NWQL). All other samples analyzed by Test America Laboratories except for NRF-16 (11-17-09) tritium sample analyzed at Brigham Young University Laboratory of Isotope Geochemistry. Pump was set at about 400 feet below land surface. Abbreviations: ${ }^{\circ} \mathrm{C}$, degrees Celsius; $\mu \mathrm{S} / \mathrm{cm}$, microsiemens per centimeter; $\mathrm{mg} / \mathrm{L}$, milligram per liter; NTU, nephlometric turbidity units; $\mathrm{CaCO}_{3}$, calcium carbonate; $\mathrm{pCi} / \mathrm{L}$, picocurie per liter; $\mathrm{N}$, nitrogen; $\mathrm{NC}$, not collected; $\mathrm{NS}$, not sampled; NA, not analyzed; PCBs, polychlorinated biphenols; USGS, U.S. Geological Survey; NRF, Naval Reactors Facility; E, estimated; <, less than]

\begin{tabular}{|c|c|c|c|c|c|c|c|}
\hline Constituent or measurement & $\begin{array}{c}\text { USGS } 17 \\
(11-03-08)\end{array}$ & $\begin{array}{c}\text { NRF-15 } \\
(11-20-08)\end{array}$ & $\begin{array}{c}\text { NRF-15 } \\
(12-10-08)\end{array}$ & $\begin{array}{c}\text { NRF-15 } \\
(12-10-08)\end{array}$ & $\begin{array}{c}\text { NRF-16 } \\
(08-26-09)\end{array}$ & $\begin{array}{c}\text { NRF-16 } \\
(11-17-09)\end{array}$ & $\begin{array}{l}\text { NRF-16 } \\
\text { (NWOL) }\end{array}$ \\
\hline \multicolumn{8}{|c|}{ Semi-volatile organic compounds-Continued } \\
\hline 4-bromophenyl phenyl ether & $<10$ & NS & NS & NS & NS & $<10$ & NS \\
\hline 4-chloro-3-methylphenol & $<10$ & NS & NS & NS & NS & $<10$ & NS \\
\hline 4-dimethylaminoazobenzene & $<20$ & NS & NS & NS & NS & $<20$ & NS \\
\hline 4-methylphenol & $<10$ & NS & NS & NS & NS & $<10$ & NS \\
\hline 4-nitroaniline & $<10$ & NS & NS & NS & NS & $<10$ & NS \\
\hline 4-nitrophenol & $<10$ & NS & NS & NS & NS & $<10$ & NS \\
\hline 4-nitroquinoline-1-oxide & NA & NS & NS & NS & NS & $<100$ & NS \\
\hline 4-phenylenediamine & NA & NS & NS & NS & NS & $<100$ & NS \\
\hline $2,4-\mathrm{D}$ & NS & NS & NS & NS & NS & $<4.0$ & NS \\
\hline Dinoseb & NS & NS & NS & NS & NS & $<1.0$ & NS \\
\hline $2,4,5-\mathrm{TP}$ & NS & NS & NS & NS & NS & $<1.0$ & NS \\
\hline $2,4,5-\mathrm{T}$ & NS & NS & NS & NS & NS & $<1.0$ & NS \\
\hline Propyzamide & $<20$ & NS & NS & NS & NS & NA & NS \\
\hline \multicolumn{8}{|c|}{ Pesticides } \\
\hline Aldrin & NS & NS & NS & NS & NS & $<.05$ & NS \\
\hline alpha-BHC & NS & NS & NS & NS & NS & $<.05$ & NS \\
\hline beta-BHC & NS & NS & NS & NS & NS & $<.05$ & NS \\
\hline Dieldrin & NS & NS & NS & NS & NS & $<.05$ & NS \\
\hline Endosulfan I & NS & NS & NS & NS & NS & $<.05$ & NS \\
\hline Endosulfan II & NS & NS & NS & NS & NS & $<.05$ & NS \\
\hline Endosulfan sulfate & NS & NS & NS & NS & NS & $<.05$ & NS \\
\hline Endrin & NS & NS & NS & NS & NS & $<.05$ & NS \\
\hline Endrin aldehyde & NS & NS & NS & NS & NS & $<.05$ & NS \\
\hline Heptachlor & NS & NS & NS & NS & NS & $<.05$ & NS \\
\hline Heptachlor epoxide & NS & NS & NS & NS & NS & $<.05$ & NS \\
\hline Isodrin & NS & NS & NS & NS & NS & $<.1$ & NS \\
\hline Kepone & NS & NS & NS & NS & NS & $<1.0$ & NS \\
\hline Methoxychlor & NS & NS & NS & NS & NS & $<.1$ & NS \\
\hline Toxaphene & NS & NS & NS & NS & NS & $<2.5$ & NS \\
\hline
\end{tabular}


Table 5. Concentrations of selected radiochemical and chemical constituents in water from wells USGS 17, NRF-15, and NRF-16, near the Naval Reactors Facility, Idaho National Laboratory, Idaho.-Continued

[Locations of wells shown in figure 2. Analytical results in micrograms per liter unless noted otherwise. Sample from well USGS 17 collected from pumped well. NRF-15 (11-20-08) sample collected from a thief sample from 394 feet below land surface. NRF-15 (12-10-08) samples collected from a thief sampler from 423 and 394 feet below land surface, respectively. NRF-16 (08-26-09) thief sample collected at about 400 feet below land surface. NRF-16 (11-17-09) samples were collected from a pumped well. NRF-16 well sampled on 11-17-09; samples analyzed at the National Water Quality Laboratory (NWQL). All other samples analyzed by Test America Laboratories except for NRF-16 (11-17-09) tritium sample analyzed at Brigham Young University Laboratory of Isotope Geochemistry. Pump was set at about 400 feet below land surface. Abbreviations: ${ }^{\circ} \mathrm{C}$, degrees Celsius; $\mu \mathrm{S} / \mathrm{cm}$, microsiemens per centimeter; mg/L, milligram per liter; NTU, nephlometric turbidity units; $\mathrm{CaCO}_{3}$, calcium carbonate; $\mathrm{pCi} / \mathrm{L}$, picocurie per liter; N, nitrogen; $\mathrm{NC}$, not collected; NS, not sampled; NA, not analyzed; PCBs, polychlorinated biphenols; USGS, U.S. Geological Survey; NRF, Naval Reactors Facility; E, estimated; <, less than]

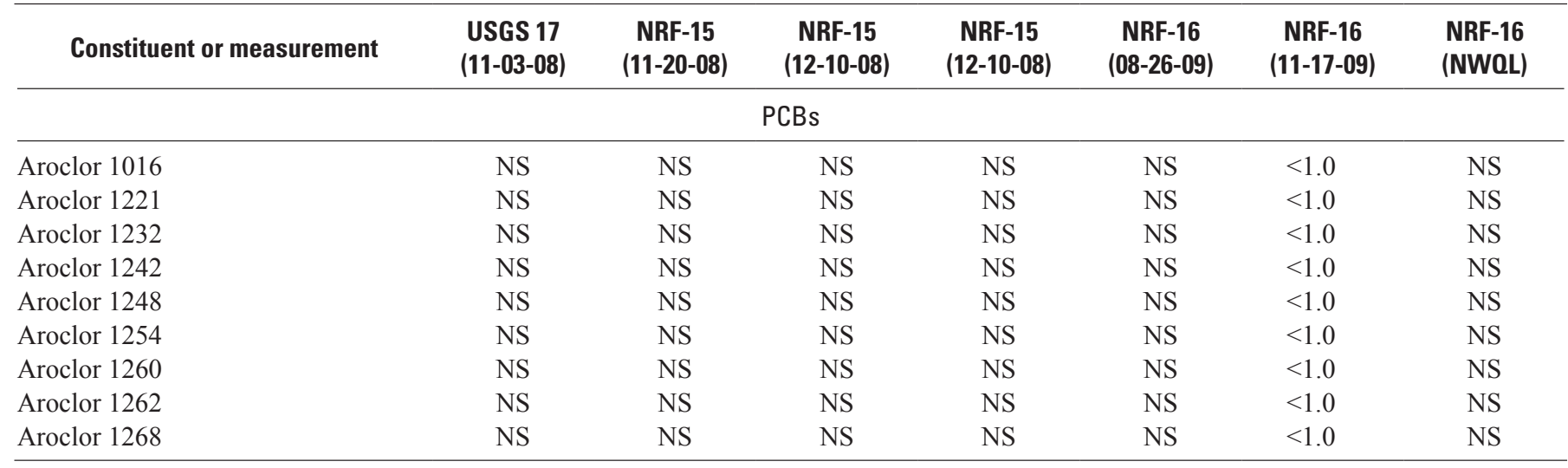

\section{Summary}

Well NRF-16 was cored and completed during August 3, 2009, through November 24, 2009, as a Comprehensive Environmental Response Compensation and Liability Act monitoring well in cooperation with the U.S. Department of Energy's Naval Reactors Laboratory Field Office, Idaho Branch Office, (NRLFO/IBO). The core from the borehole was used to interpret lithologic units, geophysical logs were collected to describe geologic and hydrologic features, two consecutive hydraulic pump tests were completed to determine hydraulic properties of the aquifer, and water samples were collected and analyzed to determine the water chemistry of the aquifer. All data collected indicate that well NRF-16 meets guidelines established for a new upgradient monitoring well for the Naval Reactors Facility (NRF) groundwater monitoring program.

Lithologic core data indicate olivine tholeiite basalt comprised 96 percent of the unsaturated zone and 100 percent of saturated zone at NRF-16. Five sediment layers, not including surficial sediment, were described as primarily fine-to-coarse alluvial sand ranging from 0.2 to 6 feet thick. Sediment layers are near 15, 65, 122, 209, and $336 \mathrm{ft}$ below land surface (BLS) with no sediment intersecting the screened section of borehole between 362 to $422 \mathrm{ft}$ BLS.

Geophysical and borehole video logs were collected after coring, reaming, and completing NRF-16. Geophysical logs indicate a complex fractured basalt stratigraphy with interbedded sediment layers. Neutron and borehole video logs collected during drilling show no evidence of perched water.
Neutron, caliper, and gamma-gamma dual density logs for the section of aquifer extending from 360 to $424 \mathrm{ft}$ BLS show water producing zones extending from 362 to $365 \mathrm{ft}$ BLS, 375 to $388 \mathrm{ft} \mathrm{BLS}, 392$ to $398 \mathrm{ft} \mathrm{BLS}$, and 403 to $406 \mathrm{ft}$ BLS. Gamma-gamma dual density logs analyzed for pre- and postcement grouting show consistent readings, which indicate that an annular seal is present from land surface to $339 \mathrm{ft}$ BLS.

Two consecutive single-well aquifer tests were conducted in the eastern Snake River Plain (SRP) aquifer to define hydraulic characteristics for NRF-16. The top of the aquifer (depth to water) is near $360 \mathrm{ft}$ BLS. This monitoring well was designed with wire wrap screen extending from 362 to $422 \mathrm{ft}$ BLS. Average transmissivity and hydraulic conductivity determined from the two aquifer tests are $4.8 \times 10^{3} \mathrm{ft}^{2} / \mathrm{d}$ and $9.9 \mathrm{ft} / \mathrm{d}$, respectively. Aquifer tests were analyzed using the Cooper-Jacob method. Estimated NRF-16 average transmissivity and hydraulic conductivity are within the range of values determined from past aquifer and tracer tests in the NRF area.

Water samples were collected from well NRF-16 following hydraulic pump testing and laboratory results for listed constituents met NRF requirements for an upgradient monitoring well. Water samples were analyzed for metals, nutrients, total organic carbon, volatile organic compounds, semi-volatile organic compounds, herbicides, pesticides, polychlorinated biphenols, and radionuclides. Water samples were analyzed for total and dissolved concentrations of calcium, magnesium, potassium, sodium, aluminum, antimony, arsenic, barium, beryllium, cadmium, chromium, copper, iron, lead, manganese, mercury, nickel, 
selenium, silver, thallium, and zinc. The dissolved constituent concentrations collected from thief samples prior to well completion were comparable with constituent concentrations collected after completion from the purged well; however, the total concentrations differed for many constituents due to particulate material in the samples collected by the thief sampler. Water samples were analyzed for total concentrations of nutrients including ammonia, nitrate plus nitrite, nitrite, orthophosphate, and total Kjedahl nitrogen and dissolved concentrations of bromide, chloride, fluoride, and sulfate. Chloride, nitrate, and sulfate concentrations were all less than background concentrations for the eastern SRP aquifer north of the NRF. Water samples for most of the organic compounds and radionuclides had concentrations below the reporting limits and reporting levels.

\section{References Cited}

Ackerman, D.J., 1991, Transmissivity of the Snake River Plain aquifer at the Idaho National Engineering Laboratory, Idaho: U.S. Geological Survey Water-Resources Investigations Report 91-4058 (DOE/ID-22097), 35 p.

Ackerman, D.J., Rattray, G.W., Rousseau, J.P., Davis, L.C., and Orr, B.R., 2006, A conceptual model of ground-water flow in the eastern Snake River Plain aquifer at the Idaho National Laboratory and vicinity with implications for contaminant transport: U.S. Geological Survey Scientific Investigations Report 2006-5122, 62 p.

Anderson, S.R., Kuntz, M.A., and Davis, L.C., 1999, Geologic controls of hydraulic conductivity in the Snake River Plain aquifer at and near the Idaho National Engineering and Environmental Laboratory, Idaho: U.S. Geological Survey Water-Resources Investigations Report 99-4033 (DOE/ ID-22155), $38 \mathrm{p}$.

Anderson, S.R., and Liszewski, M.J., 1997, Stratigraphy of the unsaturated zone and the Snake River Plain Aquifer at and near the Idaho National Engineering Laboratory, Idaho: U.S. Geological Survey Water-Resources Investigations Report 97-4183 (DOE/ID-22142), 65 p.

Barraclough, J.T., Robertson, J.B., and Janzer, V.J., 1976, Hydrology of the solid waste burial ground, as related to the potential migration of radionuclides, Idaho National Engineering Laboratory, with a section on drilling and sample analysis, by L.G. Saindon: U.S. Geological Survey Open-File Report 76-471 (IDO-22056), 183 p.

Bartholomay, R.C., Knobel, L.L., and Tucker, B.J. 1997, Chemical and radiochemical constituents in water from wells in the vicinity of the Naval Reactors Facility, Idaho National Laboratory, Idaho, 1994-1995: U.S. Geological Survey Open-File Report 97-806 (DOE/ID-22143), 70 p.
Bartholomay, R.C., Tucker, B.J., Ackerman, D.J., and Liszewski, M.J., 1997, Hydrologic conditions and distribution of selected radiochemical and chemical constituents in water, Snake River Plain aquifer, Idaho National Engineering Laboratory, Idaho, 1992 through 1995: U.S. Geological Survey Water-Resources Investigations Report 97-4086 (DOE/ID-22137), 57 p.

Busenberg, Eurybiades, Plummer, L.N., and Bartholomay, R.C., 2001, Estimated age and source of the young fraction of groundwater at the Idaho National Engineering and Environmental Laboratory: U.S. Geological Survey WaterResources Investigations Report 01-4265 (DOE/ID-22177), $144 \mathrm{p}$.

Cecil, L.D., Welhan, J.A., Green, J.R., Frape, S.K., and Sudicky, E.R., 2000, Use of chlorine-36 to determine regional-scale aquifer dispersivity, eastern Snake River Plain aquifer, Idaho/USA: Nuclear Instruments and Methods in Physics Research Section B 172, p. 679-687.

Chase, G.H., Teasdale, W.E., Ralston, D.A., and Jensen, R.G., 1964, Completion report for observation wells 1 through $49,51,54,55,56,80,81$ at the National Reactor Testing Station, Idaho: (IDO-22045), $81 \mathrm{p}$.

Childress, C.J.O., Foreman, W.T., Conner, B.F., and Maloney, T.J., 1999, New reporting procedures based on long-term method detection levels and some considerations for interpretations of water-quality data provided by the U.S. Geological Survey National Water Quality Laboratory: U.S. Geological Survey Open-File Report 99-193, 19 p.

Christensen Products, 1997, C Wireline System, http:// christensenproducts.com.

Cooper, H.H., and Jacob, C.E., 1946, A generalized graphical method for evaluating formation constants and summarizing well field history: American Geophysical Union Transactions no. 27, p. 526-534.

Currie, L.A., 1984, Lower limit of detection-definition and elaboration of a proposed position for radiological effluent and environmental measurements: U.S. Nuclear Regulatory Commission NUREG/CR-4007, 139 p.

Davis, L.C., 2008, An update of hydrologic conditions and distribution of selected constituents in water, Snake River Plain aquifer and perched-water zones, Idaho National Laboratory, Idaho, emphasis 2002-05: U.S. Geological Survey Scientific Investigations Report 2008-5089, (DOE/ ID-22203), $74 \mathrm{p}$.

Davis, L.C., Hannula, S.R., and Bowers, Beverly, 1997, Procedures for use of, and drill cores and cuttings available for study at, the lithologic core storage library, Idaho National Engineering Laboratory, Idaho: U.S. Geological Survey Open-File Report 97-124 (DOE/ID-22135), 31 p. 
Duke, C.L., Roback, R.C., Reimus, P.W., Bowman, R.S., McLing, T.L., Baker, K.E., and Hull, L.C., 2007, Elucidation of flow and transport processes in a variably saturated system of interlayered sediment and fractured rock using tracer tests: Vadose Zone Journal, v. 6, no. 4, p. 855867.

Faires, L.M., 1993, Methods of analysis by the U.S. Geological Survey National Water Quality LaboratoryDetermination of metals in water by inductively coupled plasma-mass spectrometry: U.S. Geological Survey Open-File Report 92-634, 28 p.

Fishman, M.J., ed., 1993, Methods of analysis by the U.S. Geological Survey National Water Quality LaboratoryDetermination of inorganic and organic constituents in water and fluvial sediments: U.S. Geological Survey Open-File Report 93-125, 217 p.

Fishman, M.J., and Friedman, L.C., 1989, Methods for determination of inorganic substances in water and fluvial sediments: U.S. Geological Survey Techniques of Water-Resources Investigations, book 5, chap. A1, 545 p.

Garabedian, S.P., 1986, Application of a parameter-estimation technique to modeling the regional aquifer underlying the eastern Snake River Plain, Idaho: U.S. Geological Survey Water Supply Paper 2278, 60 p.

Goerlitz, D.F., and Brown, Eugene, 1972, Methods for analysis of organic substances in water: U.S. Geological Survey Techniques of Water-Resources Investigations, book 5, chap. A3, 40 p.

Halford, K.J, Weight, W.D., and Schreiber, R.P., 2006, Interpretation of transmissivity estimates from single-well pumping aquifer tests: Ground Water, v. 44, no. 3, p. 467471 .

Keys, W.S., 1990, Borehole geophysics applied to groundwater investigations: U.S. Geological Survey Techniques of Water-Resource Investigations, book 2, chap. E2, 150 p.

Knobel, L.L., Tucker, B.J., and Rousseau, J.P., 2008, Field methods and quality-assurance plan for quality-ofwater activities, U.S. Geological Survey, Idaho National Laboratory, Idaho: U.S. Geological Survey Open-File Report 2008-1165 (DOE/ID-22206), 36 p.

Mann, L.J., 1986, Hydraulic properties of rock units and chemical quality of water for INEL-1-A 10,365-ft deep test hole drilled at the Idaho National Engineering Laboratory, Idaho: U.S. Geological Survey Water-Resources Investigations Report 86-4020 (DOE/ID-22070), 23 p.

Mann, L.J., and Beasley, T.M., 1994, Iodine-129 in the Snake River Plain aquifer at and near the Idaho National Engineering Laboratory, Idaho, 1990-91: U.S. Geological Survey Water-Resources Investigations 94-4053 (DOE/ ID-22115), $27 \mathrm{p}$.
McCurdy, D.E., Garbarino, J.R., and Mullin, A.H., 2008, Interpreting and reporting radiological water-quality data: U.S. Geological Survey Techniques and Methods, book 5, chap. B6, 33 p.

Nimmo, J.R., Perkins, K.S., Rose, P.A., Rousseau, J.P., Orr, B.R., Twining, B.V., and Anderson, S.R., 2002, Kilometerscale rapid transport of naphthalene sulfonate tracer in the unsaturated zone at the Idaho National Engineering and Environmental Laboratory: Vadose Zone Journal, v. 1, p. 89-101.

Robertson, J.B., Schoen, Robert, and Barraclough, J.T., 1974, The influence of liquid waste disposal on the geochemistry of water at the National Reactor Testing Station, Idaho: 1952-1970: U.S. Geological Survey Open-File Report 73-238 (IDO-22053), 231 p.

Rose, D.L., and Schroeder, M.P., 1995, Methods of analysis by the U.S. Geological Survey National Water Quality Laboratory - determination of volatile organic compounds in water by purge and trap capillary gas chromatography/ mass spectrometry: U.S. Geological Survey Open-File Report 94-708, 26 p.

Self, S., Keszthelyi, L., and Thordarson, Th., 1998, The importance of Pahoehoe: Annual Review of Earth and Planetary Sciences, v. 26, p. 81-110.

TestAmerica Laboratories, 2009a, Quality assurance manual: Denver, Colo., TestAmerica Analytical Testing Corp., TestAmerica, Document No. TAL QAM, Rev. 1 [variously paged].

TestAmerica Laboratories, 2009b, Quality assurance manual: St. Louis, Mo., TestAmerica Analytical Testing Corp., TestAmerica Document No. ST-QAM, Rev. 3 [variously paged].

Theis, C.V., 1935, The relation between the lowering of the piezometric surface and the rate and duration of discharge of a well using groundwater storage: Transactions of the American Geophysical Union, no. 16, p. 519-524.

U.S. Geological Survey, 1985, National water summary 1984; hydrologic events, selected water-quality trends, and ground-water resources: U.S. Geological Survey Water Supply Paper 2275, 467 p.

U.S. Geological Survey, variously dated, National field manual for the collection of water-quality data: U.S. Geological Survey Techniques of Water-Resources Investigations, Book 9, Chapters A1-A9. (Also available at http://pubs. water.usgs.gov/twri9A.)

Wershaw, R.L., Fishman, M.J., Grabbe, R.R., and Lowe, L.E., eds., 1987, Methods for determination of organic substances in water and fluvial sediments: U.S. Geological Survey Techniques of Water-Resources Investigations, book 5,chap. A3, 80 p. 
This page intentionally left blank. 


\section{Appendixes}

The appendixes can be accessed and downloaded at URL http://pubs.usgs.gov/sir/2010/5101/.

Appendix A. Chemical Material Safety Data Sheets

(Published on DVD - In pocket at back of printed report)

INTRO - Material Safety Data Sheets for chemicals used during coring and drilling NRF-16

Appendix B. Video Files

(Published on DVD - In pocket at back of printed report)

INTRO - Three Flash video files for well NRF-16 (see table 2 for depths)

NRF16 PerchedWater

NRF16 OpenHole

NRF16 Screen 
This page intentionally left blank. 
Publishing support provided by the U.S. Geological Survey Publishing Network, Tacoma Publishing Service Center

For more information concerning the research in this report, contact the Director, Idaho Water Science Center U.S. Geological Survey, 230 Collins Road Boise, Idaho 83702 http://id.water.usgs.gov 

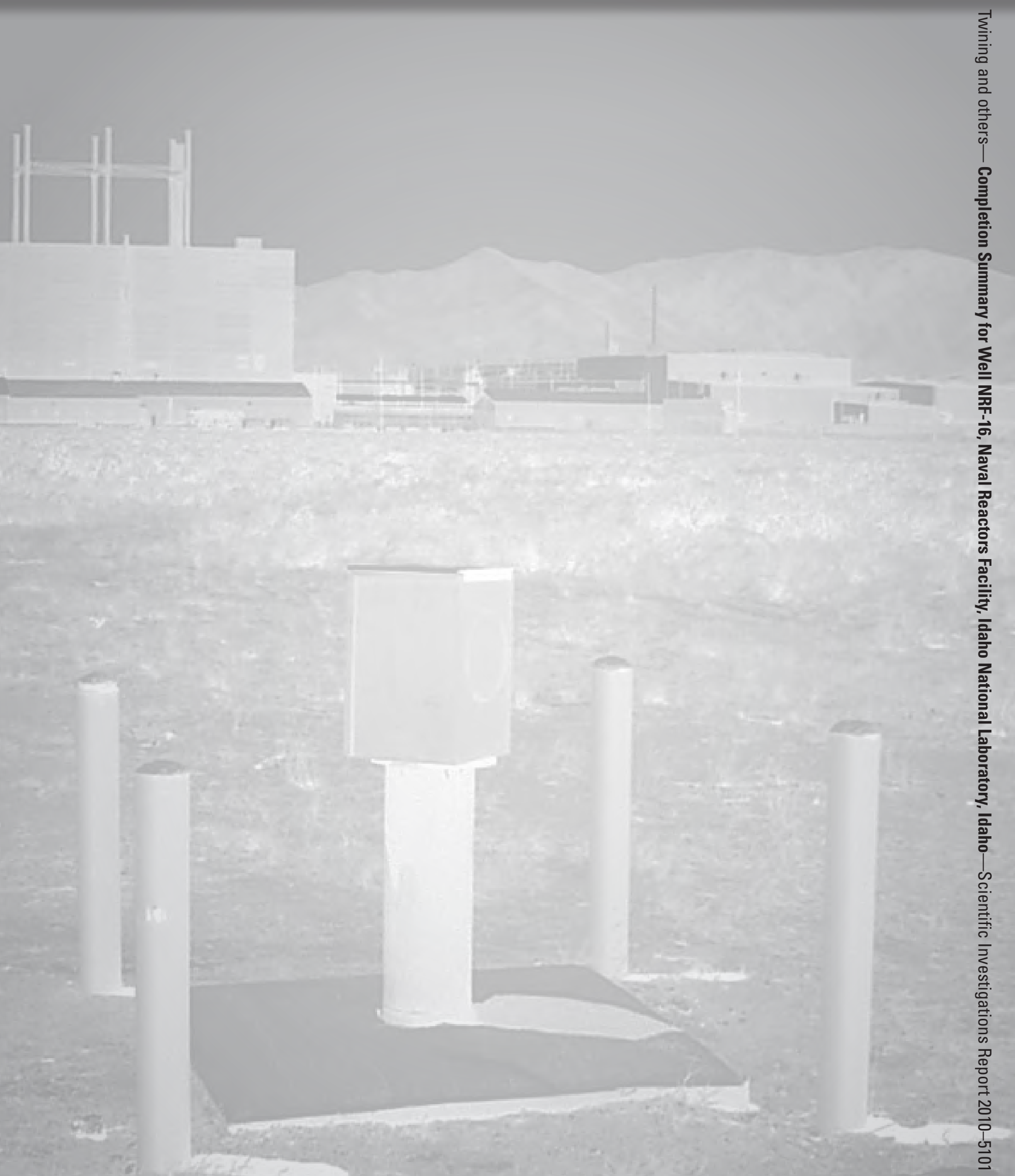